\title{
Modeling and Performance Investigations of Partially Shaded Solar PV Arrays with Cell Partition Technique based Modules
}

\author{
V. BalaRaju*, Dr. Ch. Chengaiah \\ Department of Electrical and Electronics Engineering, Sri Venkateswara University College of \\ Engineering, Tirupati, India
}

Received September 29, 2021; Accepted October 25, 2021; Published January 12, 2022

\begin{abstract}
Solar photovoltaic (PV) modules consist of solar cells connected in series to provide the required output power. The solar PV system is experiencing major challenges, which are mainly due to the partial shadows on the photovoltaic modules leading to mismatching power loss and hot spot problems. Hotspots have become a major cause of PV module failure. The Cell Partition Technique (CPT) is proposed to reduce hotspots and minimize mismatch losses caused by partial shadings. Specifically, each solar PV cell (Full cell) in a solar PV module is divided or partitioned into two half cells (known as Half-Cut Cells or HC) and three equal cells (known as Tri-Cut Cells or TC) in accordance with the proposed technique. The $\mathrm{HC}$ and TC types of cells are connected in a strings of series-parallel connection, and bypass diode is placed in middle of the solar PV module to ensure proper operation. The primary aim of this research is to model, evaluate, and investigate the performance of solar PV arrays using new PV modules are developed based on Cell Partition Technique (PVM-CPT), such as half-cut cell modules (HCM), and tri-cut cell modules (TCM) and compared with fullsized cell modules (FCM). These PVM-CPT are connected in SeriesParallel (SP), Total-Cross-Tied (TCT), and proposed static shade dispersion based TCT reconfiguration (SD-TCTR) for the array sizes of $3 \times 4,4 \times 3$ and $4 \times 4$, respectively. The purpose is to select the most appropriate solar PV array configurations in terms of the highest global maximum power and thus the lowest mismatch power losses under short and narrow, short and wide, long and narrow, long and wide type of cell level partial shadings. The Matlab/Simulink software is used to simulate and analyze all of the shading cases. The results show that, when compared to conventional module configurations under different shading conditions, the proposed static SD-TCTR arrangement with TC modules (SDTCTR-TCM) exhibits the lowest mismatch power losses and the greatest improvement in array power.
\end{abstract}

Keywords: Solar PV module; Full cell; Half cell; Tri cell; Array configurations; Static reconfigurations; Cell level shading conditions; Mismatch power losses

\section{Introduction}

Solar PV power generation is universally available, virtually endless, pollutionfree, and simple to utilize[1]. The global photovoltaic (PV) market projection (20192023) anticipated a demand to rise by $12 \%$ to $144 \mathrm{GW}$ in $2020,10 \%$ to $158 \mathrm{GW}$ in 
$2021,7 \%$ to $169 \mathrm{GW}$ in 2022 , and $6 \%$ to $180 \mathrm{GW}$ in 2023 . We anticipate that the world's total installed capacity might reach as much as 1,610 $\mathrm{GW}$ by the end of 2023 under optimal conditions[2].

While there are a variety of problems that are impeding the advancement of PV generating technology, the inherent generation efficiency of PV cells in partial shadowing conditions is one of the most significant [3-6]. Controlling PV modules with maximum power point tracking (MPPT) technology is a key strategy for maximizing the efficiency of a particular PV array [7-8]. The hotspot effect happens when the maximum current generation capacity of one or more cells in a series-connected solar cell string is dropped to values below the module's operational current. In this situation, reverse bias across cells with lesser current induces heat dissipation. Although bypass diodes are extensively utilized to safeguard the cells, the hotspot effect remains a key failure mode for silicon solar modules. It is possible to reduce resistive losses in a solar module by cutting solar cells into two, and three parts which reduces the amount of current flowing in each cell. That's why PV module efficiency can be improved by reducing the amount of power loss. New technique, to improve efficiency and reduce overall power losses, and a hotspot effect a solar cell is split into two halves or three equal parts using a laser cutting known as the Cell Partition Technique (CPT), is introduced in this work. CPT has been proposed for the development of new solar photovoltaic modules. These solar PV modules have been named as PV modules developed based on the cell partition technique (PVM-CPT). CPT uses conventional solar cells that have been cut in half and one-third to generate electricity (i.e., full cell is equally divided into two and three equal parts). Instead of having a single solar PV module with 36 or 60 or 72 full cells, the module could be divided into 72 or 120 or 144 half-sized cells and 108 or 180 or 216 tri-sized cells while maintaining the same design and dimensions as traditional modules, according to the manufacturer.

Electrical losses are calculated using the formula $\mathrm{P}_{\text {loss }}=\mathrm{I}^{2} \cdot \mathrm{R}_{\mathrm{s}}$, which is equal to the square of the electrical current multiplied by the resistance[9-10]. If a solar cell is cut into half or one-third, it will produce half or one-third of the current, and the resistance is reduced to half or one-third of the full cell resistance. Due to the fact that the power loss is proportional to the current. The half-cut cell modules minimize the power loss by a factor of four, resulting in an increase in the power produced. However, there will be twice as many of them. As a result, if they are connected to operate in the same manner as a conventional solar module, the current would be the same, but the resistance will be reduced by half. Because of the lower resistance, electrical losses are reduced, and the module efficiency is increased. Thus, half-cut and tri-cut cells improve the performance, longevity, and shade tolerance of the PV module. When a solar cell in a module string is shaded, the energy produced by the un-shaded cells is transferred as heat into the shaded cell. This creates a hot spot that can damage the solar module if it persists. It can use twice as many module cell strings to reduce heat. The lower heat production should reduce damage to the solar PV module from hot spots and boost module longevity. In half-cell and tri-cell modules, bypass diodes are used to prevent power loss from occurring from the shaded area of the module rather than the complete module. It provides a replacement path for the current to travel in the un-shaded portion of the circuit and prevents the current from passing through the shaded portion of the circuit. It minimizes the impact of shade and improves the performance of the solar PV system under shading conditions [11-14]. 
In a conventional solar PV module, a number of solar cells are connected together to form a solar module with a predetermined wattage. In the Half-cut cell and Tri-cut cell type of partial cell modules, the full cells are cut into half and one-third, respectively, and then assembled to form the module with the specified wattage. Generally, the cells are cut with the help of laser technology. Losses that occur when current is transferred from one cell to another within a module are reduced as a result of this procedure. Cutting a solar cell into half or one-third pieces minimizes the resistance loss across the entire interconnected string of solar cells in a module, resulting in increased efficiency and power output. However, power loss is proportional to the square of the current. As a result, the power loss in a half cell and tri cell is decreased by a factor of four and nine respectively. By lowering the power loss, the fill factor can be raised, which increases the cell's ability to generate more current from the available light [15-17]. By using the proposed CPT, the standard 36, 60, 72 number of full size cell modules are converted into $72,120,144$ number of half cell modules and 108,180, 216 number of tri cell modules. The new design decreases internal losses, resulting in enhanced performance in terms of energy yield, particularly during times of high irradiance.

Finally, the standard full-sized cell modules (FCM) and cell partition technique (CPT) based partial cell modules, i.e., half-cut cell modules (HCM) and tri-cut cell modules (TCM) are connected in $3 \times 4,4 \times 3$, and $4 \times 4$ array sizes with series-parallel(SP), Total-Cross-Tied(TCT), and proposed static shade dispersion based TCT reconfigurations (SD-TCTR) arrangements, and the performance under various cell level shading conditions is investigated. The "Solar Cell" package component of Matlab/Simulink (version 2018a, MathWorks, USA) was built and proven to operate basic PV modules under normal conditions (STC- Standard Test Conditions). To simulate partial shade of a module comprised of half cut cells, Tri cut cells this study only uses the Matlab/Simulink component "Solar Cell". The author did not intend to test the component because it was built on the validated double-diode replacement PV cell model. The literature has numerous concepts for modelling PV cells/modules.

The following is the structure of the paper. Section 2 describes the mathematical modeling of double diode solar PV cell and module. Section 3 presents the performance investigations of partial solar cell modules using the cell partition technique under cell level shading conditions, Section 4 discusses the proposed shade dispersion based TCT reconfiguration(SD-TCTR) using PVM-CPT in different arrays under SW, SN, LW and LN shadings. Finally, conclusions are drawn in Section 5.

\section{Mathematical Modeling of the Solar PV Cell and Module}

\subsection{Modeling of a Double Diode PV Cell and Module}

Figure 1(a) illustrates the equivalent model of the double diode photovoltaic cell. There are two anti-parallel diodes in the model, as well as series resistance and parallel resistance. Figure-1(b) shows the construction of a solar PV array, depicting the number of modules and the number of series-connected solar PV cells in each module in the array. 


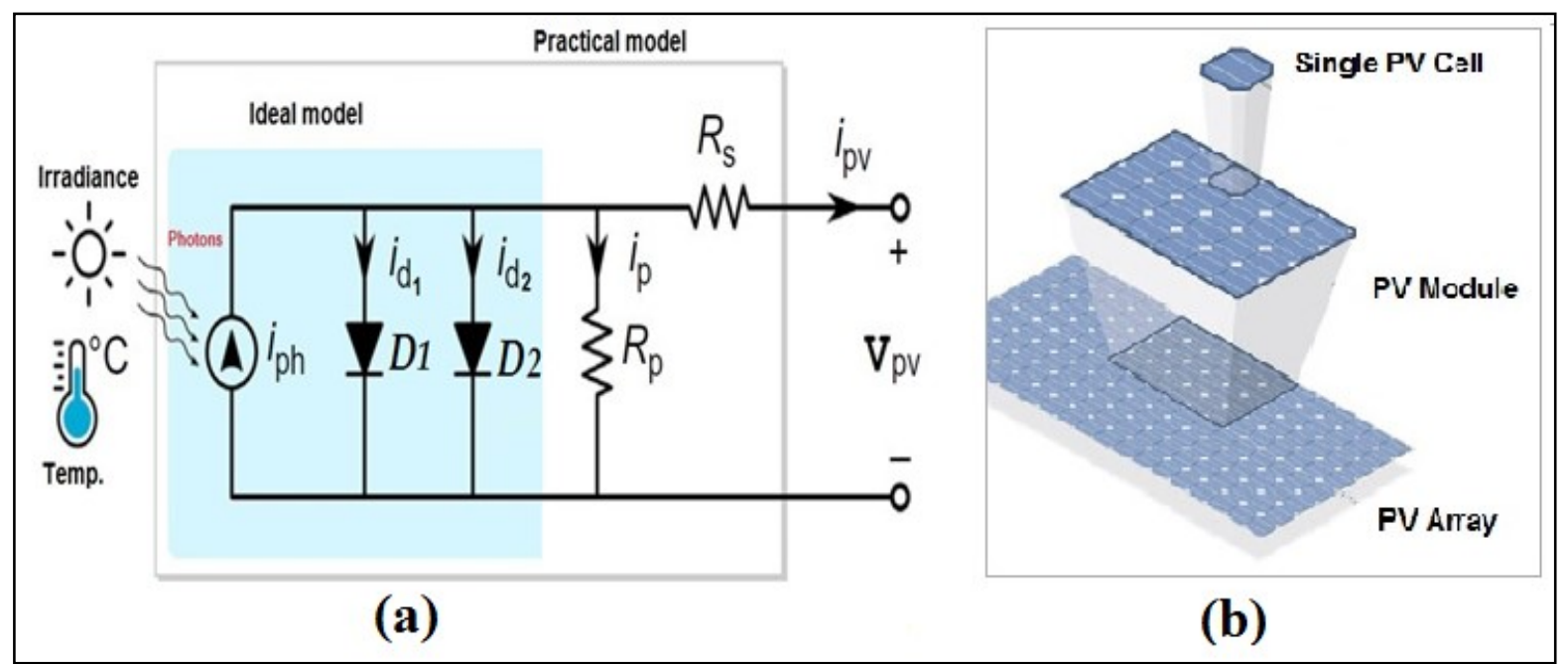

Figure 1. (a) Equivalent Double diode PV cell model. (b). Solar PV array with modules and cells

By applying Kirchhoff's current law for the PV cell model, the PV cell current is given in equation (1) [18].

$i_{p v}=i_{p h}-i_{d 1}-i_{d 2}-i_{p}$

where $i_{\text {ph }}$ is the photocurrent when the PV cell is exposed to sunlight, the anti-parallel diode currents are $i_{d 1}$ and $i_{d 2}$, and $i_{p}$ represents the parallel resistor current. Substitute the expression for $i_{p} i_{d 1}$ and $i_{d 2}$ in Equation (1). Therefore, the cell current is derived as per Equation (2).

$$
i_{p v}=i_{p h}-i_{s 1}\left[\exp \left(\frac{V_{p v}+i_{p v} \cdot R_{s}}{a_{1} \cdot V_{t}}\right)-1\right]-i_{s 2}\left[\exp \left(\frac{V_{p v}+i_{p v} \cdot R_{s}}{a_{2} \cdot V_{t}}\right)-1\right]-\left(\frac{V_{p v}+I_{p v} \cdot R_{s)}}{R_{p}}\right) \ldots
$$

where $i_{s 1}$ and $i_{s 2}$ are the reverse saturation currents of the diode D1 and D2, respectively. $\mathrm{V}_{\mathrm{t}}$ is the module thermal voltage and calculated as $\mathrm{V}_{\mathrm{t}}=\mathrm{kT} / \mathrm{q}$, where $\boldsymbol{q}$ is the electron charge with a value of $1.602 \times 10^{-19} \mathrm{C}$, Boltzmann constant as $\boldsymbol{k}=1.3806503 \times 10^{-23} \mathrm{~J} / \mathrm{K}$, and $\mathbf{T}$ is the cell temperature. $\mathrm{R}_{\mathrm{p}}$ and $\mathrm{R}_{\mathrm{s}}$ are parallel and series resistances, respectively. The $\boldsymbol{a}_{1}$ and $\boldsymbol{a}_{2}$ are the quality factors of the two diodes $\mathrm{D}_{1}$ and $\mathrm{D}_{2}$ used in the two-diode model, respectively.

The PV module is made up of solar PV cells which are connected in series and indicated by the symbol $\mathrm{N}_{\mathrm{se}}$. When $\mathrm{N}_{\mathrm{se}}$ cells are linked in series, the output current $\left(\mathrm{i}_{\mathrm{m}}\right)$ of the PV module is expressed in terms of the output voltage $\left(\mathrm{V}_{\mathrm{m}}\right)$. Equation (3) represents the total current drawn from a PV module [12].

$i_{m}=i_{p h}-i_{s 1}\left[\exp \left(\frac{q\left(V_{m}+i_{m} R_{s)}\right.}{N_{s e} a_{1} K T}\right)-1\right]-i_{s 2}\left[\exp \left(\frac{q\left(V_{m}+i_{m} R_{s)}\right.}{N_{s e} a_{2} K T}\right)-1\right]-\left(\frac{V_{m}+i_{m} R_{s} N_{s e}}{N_{s e} R_{p}}\right)$

\subsection{Solar PV Cell Parameters}

The parameters of solar cell are given in Table 1. In this paper, the solar PV modules based on cell partition technique(PVM-CPT) are developed by using two diode solar cells in the MATLAB-Simulink software. For designing a $40 \mathrm{~W}$ solar module with 
36 number of solar cells (full sized cell), the open circuit voltage $\mathrm{V}_{\text {oc }}$ and short circuit current $\mathrm{I}_{\mathrm{sc}}$ of each solar cell is taken as $0.6083 \mathrm{~V}$ and $2.45 \mathrm{~A}$, respectively. A solar cell's series resistance (Rs) is $0.0079 \Omega$ and its shunt resistance (Rsh) is set to infinity (default value) in simulink tool (as shown in Figure 2). Half cut cell (HC) and Tri cut cell (TC) in the MATLAB-Simulink is developed by considering the short circuit current of each partition cell which is half and one third of full sized cell (FC). Characteristics are given in Table 1.

Table 1. Characteristics of Solar cell used in a FC,HC, and TC PV modules

\begin{tabular}{|c|c|c|c|c|c|}
\hline SNO & Parameters of cell & $\begin{array}{c}\text { FC PV } \\
\text { Module }\end{array}$ & $\begin{array}{l}\text { HC PV } \\
\text { Module }\end{array}$ & $\begin{array}{c}\text { TC PV } \\
\text { Module }\end{array}$ & $\begin{array}{l}\text { Solar full cell } \\
\text { in simulink }\end{array}$ \\
\hline 1 & Short circuit current, $\mathrm{I}_{\mathrm{sc}}(\mathrm{A})$ & 2.45 & 1.225 & 0.8166 & \multirow{5}{*}{ 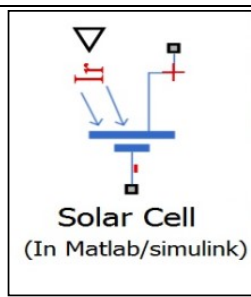 } \\
\hline 2 & Open circuit voltage, $\mathrm{V}_{\mathrm{oc}}(\mathrm{V})$ & 0.6083 & 0.6083 & 0.6083 & \\
\hline 3 & $\begin{array}{l}\text { Irradiance used for } \\
\text { measurements, } \operatorname{Irr}\left(\mathrm{W} / \mathrm{m}^{2}\right)\end{array}$ & 1000 & 1000 & 1000 & \\
\hline 4 & Temperature, $\mathrm{T}\left({ }^{0} \mathrm{C}\right)$ & $25^{0} \mathrm{C}$ & $25^{0} \mathrm{C}$ & $25^{0} \mathrm{C}$ & \\
\hline 5 & Quality factor, $\mathrm{N}$ & 1.5 & 1.5 & 1.5 & \\
\hline
\end{tabular}

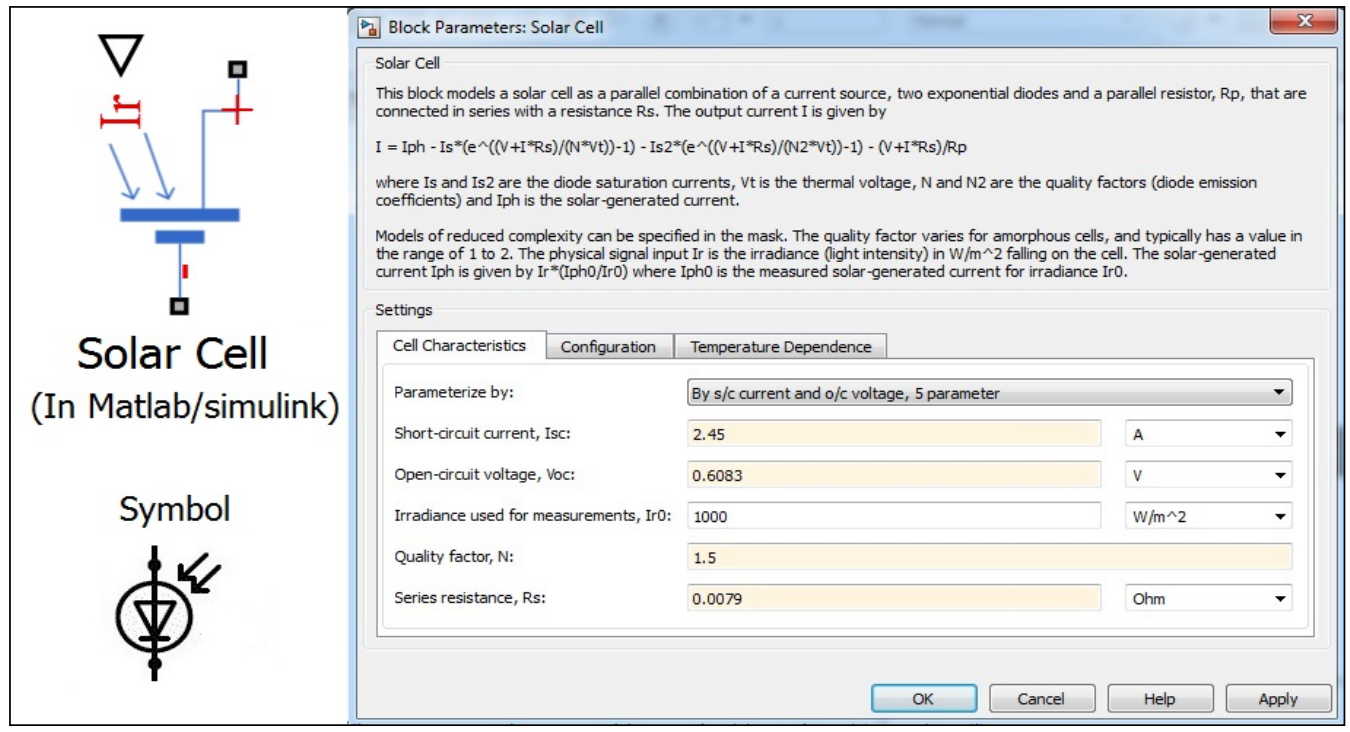

Figure 2. Parameters of Solar PV Full Cell in the MATLAB-Simulink software

\section{Performance Investigations of Partial Solar Cell Modules Using Cell Partition Technique under Cell Level Shading Conditions}

\subsection{Methodology: Cell Partition Technique (CPT)}

In general, a solar PV module is made up of a number of solar cells (full-sized cells) that are connected together in series. A cell string is formed when a number of solar cells are connected in series (creating a so-called cell string), and the sum of the single cell voltages results in a string voltage that is equal to the sum of the single cell currents. As a result, when dividing or partitioning a full-sized cell into two or three equal portions, this technique is referred to as Cell Partition Technique (CPT). This partitioning results in a $1 / 2$ or $1 / 3$ reduction in current, as well as a reduction in ohmic losses. The 
ohmic loss is dependent on the equation $\mathrm{P}_{\text {ohmic loss }}=\mathrm{I}^{2} \cdot \mathrm{R}_{\mathrm{S}}$, which describes the effect of current on the ohmic loss. Because the squared current has the greatest effect on the ohmic loss, while the series resistivity ' $\mathrm{R}_{S}$ ' has a linear effect. Electrical current ' $I$ ' flowing on bus bar is halved ' $I / 2$ ' in HCM and $I / 3$ in TCM, and Resistive losses(ohmic losses) in a HCM and TCM is $1 / 4$ and $1 / 9$ of a FCM resistive losses, respectively. The Full cell is partiotioned into a two and three equal parts using CPT, as shown in Figure 3.

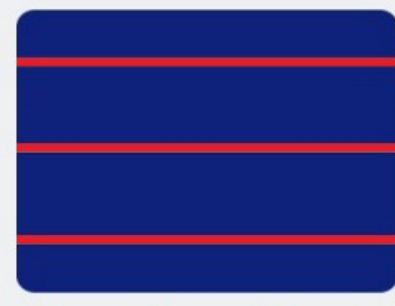

(a) Full-Cell (FC)

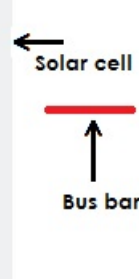

\section{(b)}
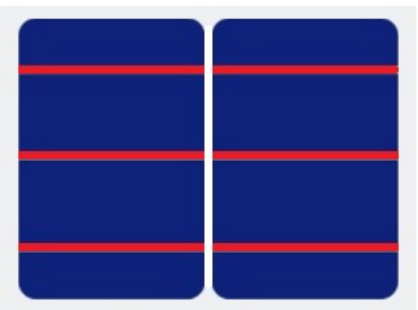

(b) Half-Cut Cell (HC)
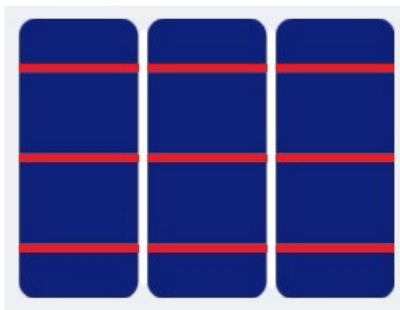

(c) Tri-Cut Cell (TC)

Figure 3. Partial Solar Cells using CPT

Utilizing halved and tri cells in solar photovoltaic modules (i.e. partial cell modules) effectively reduces resistive power loss. Halved and Tri cells are created by laser cutting, the standard full-size cells cut into half and one third, perpendicular to the busbars. The halved and tri cells are then joined and packaged into a single photovoltaic module. We outline the theory underlying the benefits of utilizing HCM and TCM in a silicon wafer-based photovoltaic module and conduct a performance analysis of PV modules developed based on CPT technique using the matlab/simulink software.

\subsection{Performance Investigations of proposed partial cell modules based on CPT Solar PV Modules based on CPT(PVM-CPT)}

The standard single PV module with 36 number of series connected Full cells (FC) to form full cell module (FCM) as shown in Figure 4(a). The full sized 36 cells are partitioned into 72 half cells and one part of 36 series connected half cells is connected in parallel to other part of 36 series connected half cells to form Half cell module (HCM) as shown in Figure 4(b). The full sized 36 cells are partitioned into 108 tri cells and one part of 54 series connected tri cells is connected in parallel to other part of 54 series connected tri cells to form a Tri cell module (TCM) as illustrated in Figure 4(c). Bypass diodes (BD's) are connected in each solar PV module to bypass the solar cells under shading cases. The electrical power generated by the FCM, HCM and TCM is approximately $40.02 \mathrm{~W}, 40.75 \mathrm{~W}$, and $41 \mathrm{~W}$ respectively with an open circuit voltage of $0.6083 \mathrm{~V}$. Standard FCM and partial cell PV modules, i.e., HCM and TCM, with representative current flow through cell strings $(1,2,3,4)$ and bypass diodes $(a, b)$, as illustrated in Figures. 5(a), 5(b), and 5(c)[19].

A standard solar module (developed in this paper is a $40 \mathrm{~W}$ module with 36 full cells) has two internal cell strings. The HCM and TCM, on the other hand, have four internal cell strings, making it a four string module instead of two strings. A single minor spot of shade on a module (such as a leaf or bird dropping) will disable the entire cell string, but will have no effect on the others. This is due to the bypass diodes (shown in black color in Figure 5). Partially shaded cells are less severe in the half-cut and Tri-cut cell modules since they have more strings. The internal cell strings of FCM is 2, while the internal cell strings of HCM and TCM are 4 (with only two bypass diodes), resulting 
in improved partial-shade tolerance. Even if half of the module is shaded, the other half is still capable of operating and generating electricity

\section{Shading Loss, Resistive Loss and Hotspot-Heating in Partial Cell Modules}

Due to the difference in current between the two parts of the cell, the shading loss in half-cut cells and tri-cut cells is insignificant. If half of the string cells are shaded, that region is affected, and the bypass diode for that half of the string cells will be activated. Meanwhile, the other half of the string cells is still in action, and the bypass diode for that half of the string cells will be inactive. The power generated by the other half of the cell is unaffected by this event. With reference to Table 2, which depicts bypass diode $\boldsymbol{a}$ and $\boldsymbol{b}$ as a white triangle, and internal cell strings as 1,2,3, and 4, this becomes evident. As a result, half-cut or tri-cut cells are favoured over conventional cells in order to reduce shading losses. The use of series-parallel-series connections in half-cut and tri-cut cell modules (HCM and TCM) significantly reduces the amount of heat lost. Half-cut and tricut cells, for example, have a lower temperature rise in a hotspot cell than full-cut cells, which reduces the degradation caused by such a situation. In partial shading, the module can save up to $50 \%$ of its power because the strings are configured in parallel. It is also less likely that there will be hotspots due to shading in the future. With regard to the series resistance of a module made of silicon wafer solar cells, it can be divided into two categories: First, there is the series resistance of the cell (which includes bulk silicon resistance, metal semiconductor contact resistance, and resistance of metal electrodes), and second, there is the series resistance of the ribbons (which includes resistance of the ribbons and metal electrode resistance). The relationship between ohmic loss and current is $\mathrm{P}_{\text {ohmic loss }}=\mathrm{I}^{2} \cdot \mathrm{R}_{\mathrm{S}}$, and the ohmic loss of partial cell modules is lower than that of a normal full cell PV module.

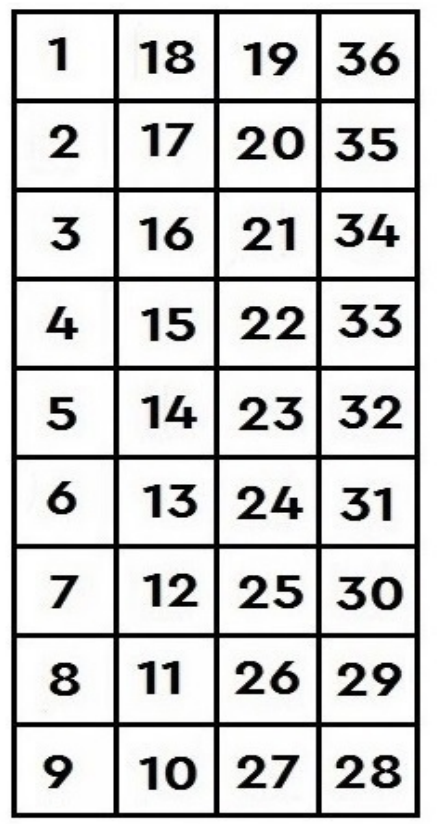

(a) 36 Full Cells with 2 BD's

\begin{tabular}{|c|c|c|c|}
\hline 9 & 10 & 27 & 28 \\
\hline 8 & 11 & 26 & 29 \\
\hline 7 & 12 & 25 & 30 \\
\hline 6 & 13 & 24 & 31 \\
\hline 5 & 14 & 23 & 32 \\
\hline 4 & 15 & 22 & 33 \\
\hline 3 & 16 & 21 & 34 \\
\hline 2 & 17 & 20 & 35 \\
\hline 1 & 18 & 19 & 36 \\
\hline \hline 37 & 54 & 55 & 72 \\
\hline 38 & 53 & 56 & 71 \\
\hline 39 & 52 & 57 & 70 \\
\hline 40 & 51 & 58 & 69 \\
\hline 41 & 50 & 59 & 68 \\
\hline 42 & 49 & 60 & 67 \\
\hline 43 & 48 & 61 & 66 \\
\hline 44 & 47 & 62 & 65 \\
\hline 45 & 46 & 63 & 64 \\
\hline
\end{tabular}

(b) 72 Half Cells with 2 BD's

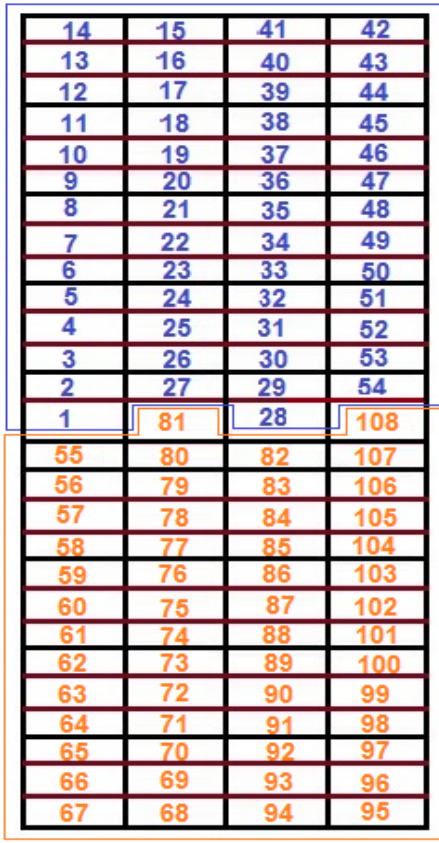

(c) 108 Tri Cells with 2 BD's

Figure 4. Illustration of Standard 36 Full Cell module and Proposed PV modules using 72 Half Cells, and 108 Tri Cells with two BD's 


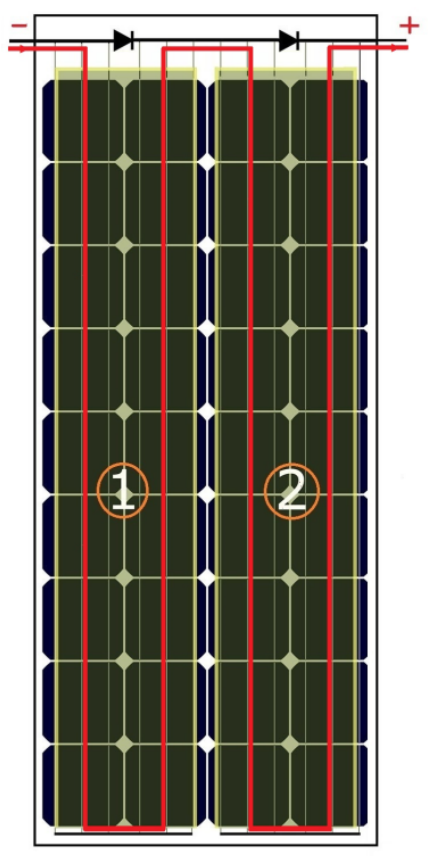

(a) 32 Full Cells: FCM

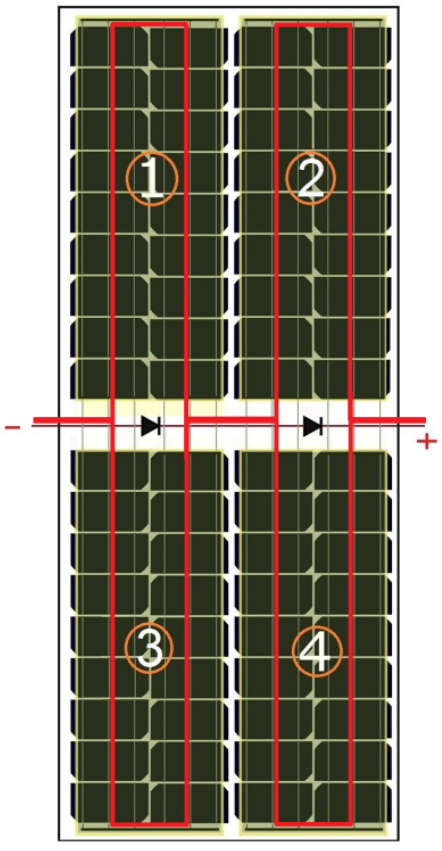

(b) 72 Half Cut Cells: HCM

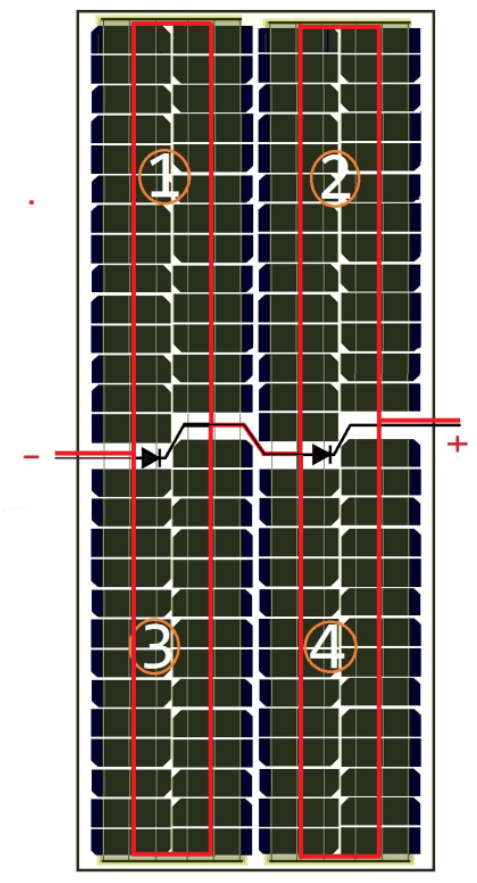

(c) 108 Tri Cut Cells: TCM

Figure 5. Illustration of Standard FCM and Proposed Partial Cell Modules with two BD's

\subsection{Effect of Internal Cell String Shading in FCM, HCM and TCM}

The amount of power that a single solar PV module can produce in the Simulink software with 36 full cells, 72 half-cut cells and 108 tri-cut cells are approximately $40.02 \mathrm{~W}, 40.75 \mathrm{~W}$, and $41 \mathrm{~W}$. The standard $40 \mathrm{~W}$ FCM has two internal strings of cell but HCM, and TCM has four internal strings of cells as exposed in Figure 5. One string is made up of a total of 18 cells that are connected together in a series. The voltage, current, and power of a solar FCM, HCM, and TCM under different internal cell string shadings at irradiance of $0 \mathrm{~W} / \mathrm{m}^{2}$ are given in Table 2 .

\section{Operation of FCM, HCM and TCM under Cell String Shadings}

Figure 5 illustrates the 36 full cell module, 72 half-cell module, and 108 tri-cell module. The power output( $\mathrm{Wp}$ means watts peak) of standard single full cell module is approximately $40 \mathrm{~W}$. The operation of FCM, HCM and TCM with two bypass diodes (a, b) at irradiance of $0 \mathrm{~W} / \mathrm{m}^{2}$ are clearly elaborated in Table 2. It should be noted that all modules receive full irradiance of $1000 \mathrm{~W} / \mathrm{m}^{2}$ in the uniform irradiance case and in cases 1 to 6 , the modules receive irradiances of $0 \mathrm{~W} / \mathrm{m}^{2}$ and $500 \mathrm{~W} / \mathrm{m}^{2}$. The simulation results for shading cases 1 to 6 are given in tables 3 to 8 .

Under uniform irradiance case (Case-U): All modules of FCM, HCM and TCM are generating full output power of approximately $40.02 \mathrm{~W}, 40.75 \mathrm{~W}$, and $41 \mathrm{~W}$ respectively. In this case, two diodes 1 and 2 are inactive.

Under shading case-1: In this case, first string of half cells is shaded. In FCM, the diode$\mathbf{a}$ is active and it bypassing shaded string- 1 and diode-b is inactive. In HCM and TCM, diode-2 is inactive and diode-a is active. So shaded string-3 is bypassed and power is still being produced by top string- 1 .

Under shading case-2: In this case, cells in bottom left string are shaded. The diode- a is active, i.e., bypassing shaded string and diode- $\mathbf{b}$ is inactive in FCM, HCM and TCM. 
Under shading case-3: In this case, half cells shaded in two strings. The diode-a is active, diode- $\mathbf{b}$ is active, and it bypassing shaded strings in FCM, HCM and TCM.

Under shading case-4: In this case, bottom module cells are shaded. The diode-a is active, diode- $\mathbf{b}$ is active in FCM, HCM and TCM, and it bypassing shaded strings.

Under shading case-5: In this case, one cell shaded in string. The diode-a is active: bypassing shaded string and diode- $\mathbf{b}$ is inactive in FCM, HCM and TCM.

Under shading case-6: In this case, bottom cells shaded in solar PV module. Two diodes are active in FCM. The diode- $\mathbf{a}$ is active: bypassing shaded string and diode-b is inactive in HCM and TCM.

Table 2. Effect of internal cell string shadings at irradiance of $0 \mathrm{~W} / \mathrm{m}^{2}$ in $\mathrm{FCM}$, $\mathrm{HCM}$, and TCM with bypass diodes $(a, b)$

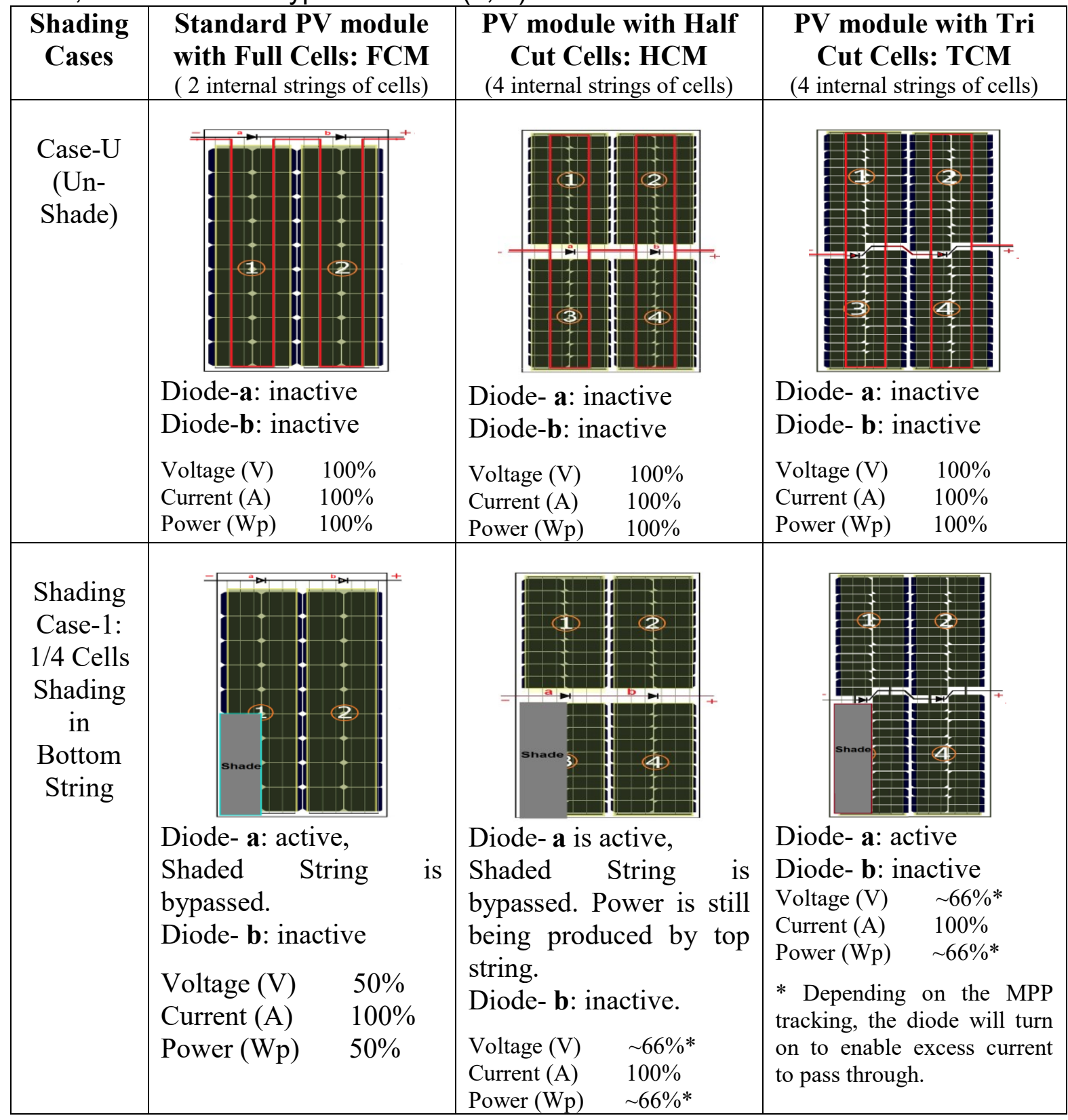




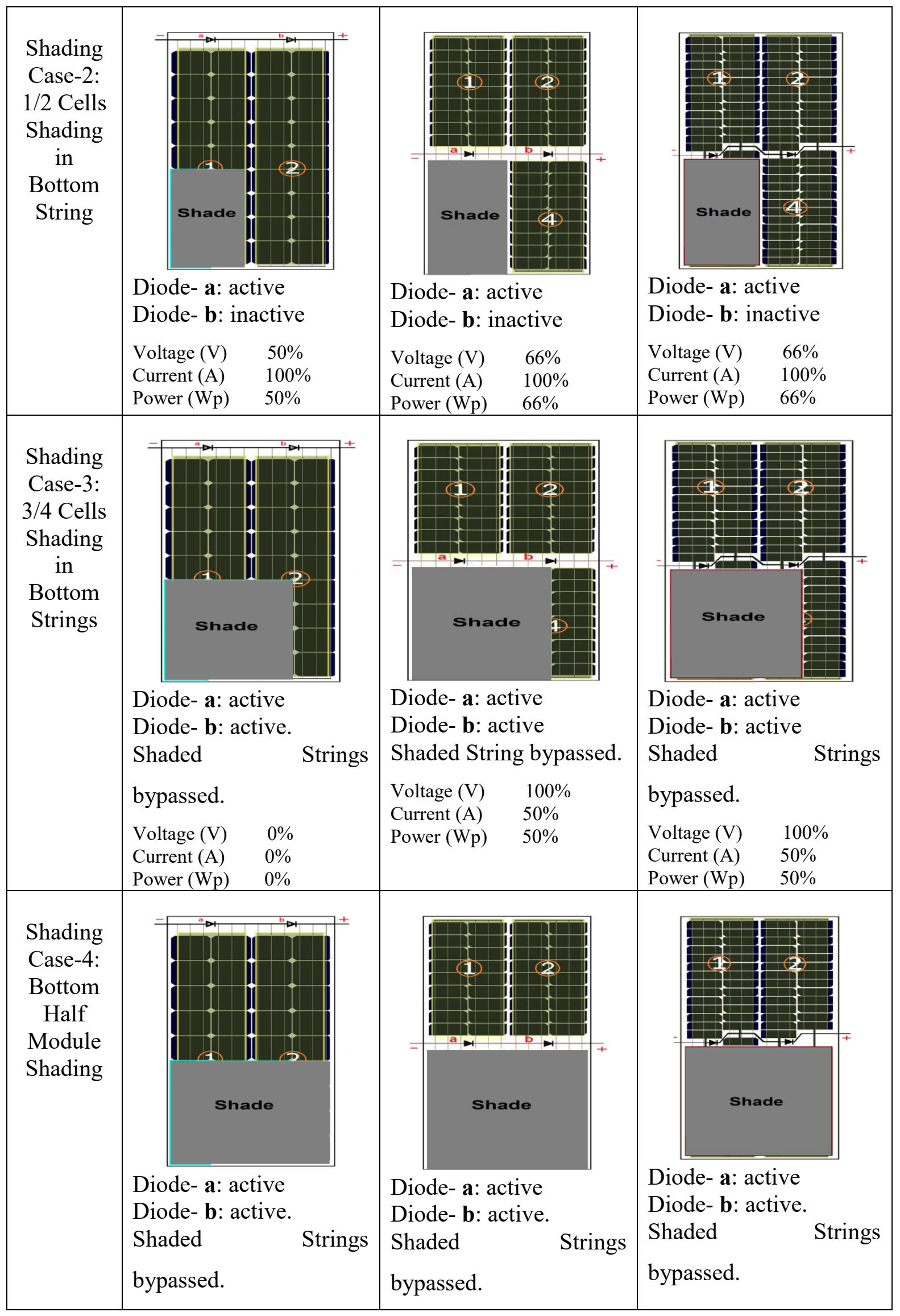




\begin{tabular}{|c|c|c|c|c|c|}
\hline & $\begin{array}{ll}\text { Voltage (V) } & 0 \% \\
\text { Current (A) } & 0 \% \\
\text { Power (Wp) } & 0 \% \\
\end{array}$ & $\begin{array}{l}\text { Voltage (V) } \\
\text { Current (A) } \\
\text { Power (Wp) }\end{array}$ & $\begin{array}{l}100 \% \\
50 \% \\
50 \% \\
\end{array}$ & $\begin{array}{l}\text { Voltage (V) } \\
\text { Current (A) } \\
\text { Power (Wp) }\end{array}$ & $\begin{array}{l}100 \% \\
50 \% \\
50 \% \\
\end{array}$ \\
\hline $\begin{array}{c}\text { Shading } \\
\text { Case-5: } \\
\text { One Cell } \\
\text { Shading } \\
\text { in } \\
\text { A String }\end{array}$ & 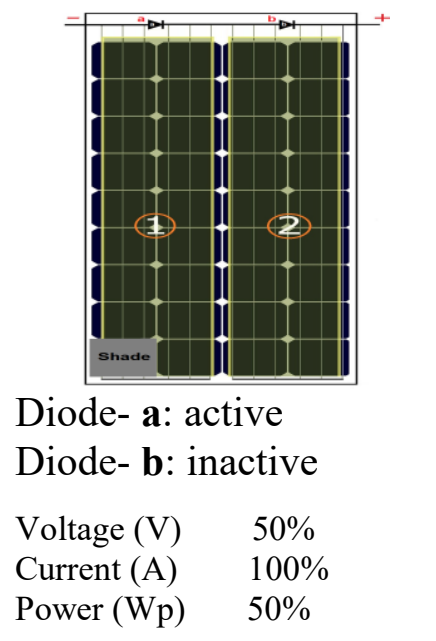 & \multicolumn{2}{|c|}{$\begin{array}{l}\text { Diode- } \mathbf{a}: \text { active } \\
\text { Diode- } \mathbf{b} \text { : inactive }\end{array}$} & \multicolumn{2}{|c|}{$\begin{array}{l}\text { Diode- } \mathbf{a}: \text { active } \\
\text { Diode- } \mathbf{b}: \text { inactive }\end{array}$} \\
\hline $\begin{array}{l}\text { Shading } \\
\text { Case-6: } \\
\text { Bottom } \\
\text { Cells } \\
\text { Shading } \\
\text { in Strings }\end{array}$ & $\begin{array}{l}\text { Diode- a: active } \\
\text { Diode- b: active } \\
\text { Shaded } \\
\text { bypassed. } \\
\text { Voltage (V) } \quad 0 \% \\
\text { Current (A) } \quad 0 \% \\
\text { Power (Wp) } 0 \%\end{array}$ & $\begin{array}{l}\text { Diode- a: } \\
\text { Diode- b: } \\
\text { Shaded } \\
\text { bypassed. } \\
\text { Voltage (V) } \\
\text { Current (A) } \\
\text { Power (Wp) }\end{array}$ & $\begin{array}{l}\text { ive } \\
\text { Strings } \\
100 \% \\
50 \% \\
50 \%\end{array}$ & $\begin{array}{l}\text { Dhaded } \\
\text { Diode- } \mathbf{b}: \text { a } \\
\text { bypassed. } \\
\text { Voltage (V) } \\
\text { Current (A) } \\
\text { Power (Wp) }\end{array}$ & $\begin{array}{l}\text { ive } \\
\text { ive } \\
\text { Strings } \\
\\
100 \% \\
50 \% \\
50 \%\end{array}$ \\
\hline
\end{tabular}

The simulation results of a single FCM, HCM and TCM under six internal cell string shading conditions (shown in Table 2) with irradiance of $0 \mathrm{~W} / \mathrm{m}^{2}$ and $500 \mathrm{~W} / \mathrm{m}^{2}$ are tabulated in Tables 3 to 8 . The mismatch loss and fill factor formulas are given below.

Mismatch losses $M L($ in watts $)=G M P P_{\text {uni }}-G M P P_{S C s}$

Mismatch losses, $M L(\%)=\frac{G M P P_{u n i}-G M P P_{s c}}{G M P P_{u n i}} \times 100$

Fill Factor, $F F(\%)=\frac{V_{m} \cdot I_{m}}{V_{o c} \cdot I_{s c}} \times 100$ 
Where, $G M P P_{u n i}$ is the global maximum peak power (in watts) at uniform irradiance of $1000 \mathrm{~W} / \mathrm{m}^{2}, G M P P_{s c}$ is the global maximum peak power(in watts) in shading cases. $V_{m}$ and $I_{m}$ are the maximum voltage (in Volts) and the maximum current (in Amperes), respectively. $V_{o c}$ is open circuit voltage (in Volts) and $I_{s c}$ is short circuit current (in Amperes) of solar PV module.

Table 3. Performance of 36 cell FCM with 2BD's under irradiance of $0 \mathrm{~W} / \mathrm{m}^{2}$

\begin{tabular}{|c|c|c|c|c|c|c|c|c|}
\hline \multirow{2}{*}{$\begin{array}{l}\text { Shadin } \\
\text { g Cases }\end{array}$} & \multicolumn{8}{|c|}{ Standard Full Cell Module (FCM) with 36 Full Cells } \\
\hline & $\operatorname{Pmax}(\mathrm{W}$ & $\mathrm{Vmax}(\mathrm{V}$ & $\operatorname{Im}(\mathrm{A}$ & Voc(V & Isc(A & ML(W) & $\operatorname{ML}(\%$ & FF \\
\hline Case-U & 40.02 & 17.72 & 2.258 & 21.9 & 2.45 & 0 & 0 & 0.746 \\
\hline Case-1 & 29.82 & 13.26 & 2.248 & 16.72 & 2.45 & 10.20 & 25.49 & 0.728 \\
\hline Case-2 & 18.83 & 8.402 & 2.241 & 10.45 & 2.45 & 21.19 & 52.95 & 0.735 \\
\hline Case-3 & 0 & 0 & 0 & 0 & 0 & 40.02 & 100 & 0 \\
\hline Case-4 & 0 & 0 & 0 & 0 & 0 & 40.02 & 100.00 & 0 \\
\hline Case-5 & 18.83 & 8.402 & 2.241 & 10.45 & 2.45 & 21.19 & 52.95 & 0.735 \\
\hline Case-6 & 0 & 0 & 0 & 0 & 0 & 0 & 0 & 0 \\
\hline
\end{tabular}

Table 4. Performance of 36 cell FCM with 2BD's under irradiance of $500 \mathrm{~W} / \mathrm{m}^{2}$

\begin{tabular}{|c|c|c|c|c|c|c|c|c|}
\hline \multirow{2}{*}{$\begin{array}{l}\text { Shadin } \\
\text { g Cases }\end{array}$} & \multicolumn{8}{|c|}{ Standard Full Cell Module (FCM) with 36 Full Cells } \\
\hline & $\operatorname{Pmax}(\mathrm{W}$ & $\operatorname{Vmax}(\mathrm{V}$ & $\operatorname{Im}(\mathrm{A}$ & Voc(V & Isc(A & $\mathrm{ML}(\mathrm{W})$ & $\operatorname{ML}(\%$ & FF \\
\hline Case-U & 40.02 & 17.72 & 2.258 & 21.9 & 2.45 & 0 & 0 & 0.7457 \\
\hline Case-1 & 29.9 & 13.34 & 2.242 & 21.76 & 2.45 & 10.12 & 25.29 & 0.5610 \\
\hline Case-2 & 22.94 & 19.19 & 1.195 & 21.61 & 2.45 & 7.08 & 42.68 & 0.4331 \\
\hline Case-3 & 22.1 & 18.68 & 1.183 & 21.49 & 2.45 & 17.92 & 44.78 & 0.4197 \\
\hline Case-4 & 21.34 & 18.27 & 1.168 & 21.36 & 1.225 & 18.68 & 46.68 & 0.8155 \\
\hline Case-5 & 24.88 & 20.35 & 1.222 & 21.86 & 2.45 & 15.14 & 37.83 & 0.4643 \\
\hline Case-6 & 0 & 0 & 0 & 0 & 0 & 0 & 0 & 0 \\
\hline
\end{tabular}

Table 5. Performance of HCM with 2BD's under irradiance of $0 \mathrm{~W} / \mathrm{m}^{2}$

\begin{tabular}{|c|c|c|c|c|c|c|c|c|}
\hline \multirow{2}{*}{$\begin{array}{l}\text { Shadin } \\
\text { g Cases }\end{array}$} & \multicolumn{8}{|c|}{ Half Cell Module(HCM) with 72 Half Cells } \\
\hline & $\operatorname{Pmax}(\mathrm{W}$ & ${ }) \max (\mathrm{V}$ & $\operatorname{Im}(\mathrm{A}$ & $\begin{array}{l}\operatorname{Voc}(\mathrm{V} \\
)\end{array}$ & ${ }_{\text {Isc(A }}^{\text {Isc }}$ & $\mathrm{ML}(\mathrm{W})$ & $\begin{array}{l}\operatorname{ML}(\% \\
)\end{array}$ & $\mathrm{FF}$ \\
\hline Case-U & 40.75 & 18 & 2.264 & 21.9 & 2.45 & 0.00 & 0.00 & 0.7595 \\
\hline Case-1 & 22.28 & 18.97 & 1.174 & 21.6 & 2.45 & 18.47 & 45.33 & 0.4208 \\
\hline Case-2 & 21.83 & 18.54 & 1.177 & 21.4 & 2.45 & 18.92 & 46.43 & 0.4162 \\
\hline Case-3 & 19.88 & 17.61 & 1.129 & 21.11 & 1.225 & 20.87 & 51.21 & 0.7688 \\
\hline Case-4 & 19.46 & 17.23 & 1.13 & 20.92 & 1.225 & 21.29 & 52.25 & 0.7597 \\
\hline Case-5 & 22.3 & 18.98 & 1.175 & 21.82 & 2.45 & 18.45 & 45.28 & 0.4172 \\
\hline Case-6 & 20.38 & 18 & 1.132 & 21.89 & 1.225 & 20.37 & 49.99 & 0.7599 \\
\hline
\end{tabular}


Table 6. Performance of HCM with 2BD's under irradiance of $500 \mathrm{~W} / \mathrm{m}^{2}$

\begin{tabular}{|c|c|c|c|c|c|c|c|c|}
\hline \multirow{2}{*}{$\begin{array}{l}\text { Shadin } \\
\text { g Cases }\end{array}$} & \multicolumn{8}{|c|}{ Half Cell Module(HCM) with 72 Half Cells } \\
\hline & $\operatorname{Pmax}(\mathrm{W}$ & $\mathrm{Vmax}(\mathrm{V}$ & $\operatorname{Im}(\mathrm{A}$ & Voc(V & $\begin{array}{l}\operatorname{Isc}(\mathrm{A} \\
)\end{array}$ & $\operatorname{ML}(\mathrm{W})$ & $\begin{array}{l}\operatorname{ML}(\% \\
)\end{array}$ & $\mathrm{FF}$ \\
\hline Case-U & 40.75 & 18 & 2.264 & 21.9 & 2.45 & 0.00 & 0.00 & 0.7595 \\
\hline Case-1 & 33.02 & 18.71 & 1.765 & 21.79 & 2.45 & 7.73 & 18.97 & 0.6055 \\
\hline Case-2 & 32.33 & 18.42 & 1.755 & 21.69 & 2.45 & 8.42 & 20.66 & 0.6083 \\
\hline Case-3 & 30.62 & 17.93 & 1.708 & 21.58 & 1.838 & 10.13 & 24.86 & 0.7721 \\
\hline Case-4 & 30.02 & 17.71 & 1.695 & 21.49 & 1.838 & 10.73 & 26.33 & 0.7803 \\
\hline Case-5 & 33.12 & 18.82 & 1.759 & 21.88 & 2.45 & 7.63 & 18.72 & 0.6175 \\
\hline Case-6 & 20.38 & 18 & 1.132 & 21.89 & 1.225 & 20.37 & 49.99 & 0.7599 \\
\hline
\end{tabular}

Table 7. Performance of TCM with 2BD's under irradiance of $0 \mathrm{~W} / \mathrm{m}^{2}$

\begin{tabular}{|c|c|c|c|c|c|c|c|c|}
\hline \multirow{2}{*}{$\begin{array}{l}\text { Shadin } \\
\text { g Cases }\end{array}$} & \multicolumn{8}{|c|}{ Tri Cell Module(TCM) with 108 Tri Cells } \\
\hline & $\operatorname{Pmax}(\mathrm{W}$ & $\mathrm{Vmax}(\mathrm{V}$ & $\operatorname{Im}(\mathrm{A}$ & $\begin{array}{l}\operatorname{Voc}(\mathrm{V} \\
{ }^{2}\end{array}$ & ${ }^{\mathrm{Isc}}(\mathrm{A}$ & $\mathrm{ML}(\mathrm{W})$ & $\begin{array}{l}\text { ML(\% } \\
\text { ) }\end{array}$ & FF \\
\hline Case-U & 41 & 27.27 & 1.503 & 32.84 & 1.633 & 0.00 & 0.00 & 0.7643 \\
\hline Case-1 & 22.37 & 28.61 & 0.782 & 32.42 & 1.633 & 18.61 & 45.41 & 0.4226 \\
\hline Case-2 & 21.89 & 27.96 & 0.783 & 32.11 & 1.633 & 19.09 & 46.58 & 0.4175 \\
\hline Case-3 & 19.98 & 26.38 & 0.757 & 31.7 & 0.816 & 21.00 & 51.24 & 0.7717 \\
\hline Case-4 & 19.52 & 25.75 & 0.758 & 31.38 & 0.816 & 21.46 & 52.37 & 0.7618 \\
\hline Case-5 & 22.39 & 28.62 & 0.782 & 32.74 & 1.633 & 18.59 & 45.36 & 0.4188 \\
\hline Case-6 & 20.5 & 27.05 & 0.757 & 32.84 & 0.816 & 20.48 & 49.97 & 0.7641 \\
\hline
\end{tabular}

Table 8. Performance of TCM with 2BD's under irradiance of $500 \mathrm{~W} / \mathrm{m}^{2}$

\begin{tabular}{|c|c|c|c|c|c|c|c|c|}
\hline \multirow{2}{*}{$\begin{array}{l}\text { Shadin } \\
\text { g Cases }\end{array}$} & \multicolumn{8}{|c|}{ Tri Cell Module(TCM) with 108 Tri Cells } \\
\hline & $\operatorname{Pmax}(\mathrm{W}$ & $\mathrm{Vmax}(\mathrm{V}$ & $\operatorname{Im}(\mathrm{A}$ & Voc(V & Isc(A & ML(W) & $\operatorname{ML}(\%$ & FF \\
\hline Case-U & 41 & 27.27 & 1.503 & 32.84 & 1.633 & 0 & 0 & 0.7643 \\
\hline Case-1 & 33.17 & 27.91 & 1.188 & 32.66 & 1.633 & 7.81 & 19.06 & 0.6217 \\
\hline Case-2 & 32.48 & 27.62 & 1.176 & 32.52 & 1.633 & 8.50 & 20.74 & 0.6116 \\
\hline Case-3 & 30.78 & 26.89 & 1.145 & 32.38 & 1.225 & 10.20 & 24.89 & 0.7762 \\
\hline Case-4 & 30.16 & 26.62 & 1.133 & 32.22 & 1.225 & 10.82 & 26.40 & 0.7641 \\
\hline Case-5 & 33.27 & 28.47 & 1.169 & 32.83 & 1.633 & 7.71 & 18.81 & 0.6208 \\
\hline Case-6 & 20.5 & 27.05 & 0.757 & 32.84 & 0.816 & 20.48 & 49.97 & 0.7641 \\
\hline
\end{tabular}

Based on the findings of the simulations presented above, it can be deduced that the performance of HCM and TCM is better compared to FCM under internal cell strings shading conditions.

\subsection{Effects of Cell Level Shadings on PVM - CPT}

Shading occurs due to several factors like clouds, trees, nearby buildings, etc. It effects the output power of an solar PV module. In the literature, all researchers elucidated module level partial shading conditions only not cell level shading conditions. The novelty of this research is in the investigation of the performance of PVM-CPT under various cell level shading conditions. Figures 6, 7, and 8 display the FCM, HCM, 
and TCM modules, which represent different cell level shading cases. The performance of PVM-CPT are analyzed under twelve cell level shadings with different irradiances and one uniform case (Case-U) with irradiance of $1000 \mathrm{~W} / \mathrm{m}^{2}$. The performance of a standard FCM with 36 cells is studied using 12 shadings at the cell level, as exposed in Figure 6.

\begin{tabular}{|l|l|l|l|}
\hline 1 & 18 & 19 & 36 \\
\hline 2 & 17 & 20 & 35 \\
\hline 3 & 16 & 21 & 34 \\
\hline 4 & 15 & 22 & 33 \\
\hline 5 & 14 & 23 & 32 \\
\hline 6 & 13 & 24 & 31 \\
\hline 7 & 12 & 25 & 30 \\
\hline 8 & 11 & 26 & 29 \\
\hline 9 & 10 & 27 & 28 \\
\hline
\end{tabular}

Case-U

\begin{tabular}{|l|l|l|l|}
\hline 1 & 18 & 19 & 36 \\
\hline 2 & 17 & 20 & 35 \\
\hline 3 & 16 & 21 & 34 \\
\hline 4 & 15 & 22 & 33 \\
\hline 5 & 14 & 23 & 32 \\
\hline 6 & 13 & 24 & 31 \\
\hline 7 & 12 & 25 & 30 \\
\hline 8 & 11 & 26 & 29 \\
\hline 500 & 10 & 27 & 28 \\
\hline
\end{tabular}

Case-7

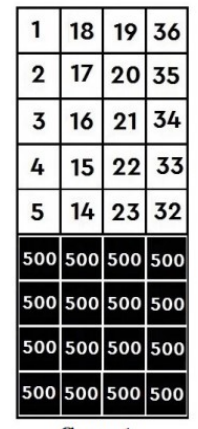

Case-1

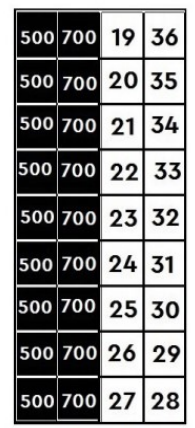

Case-2

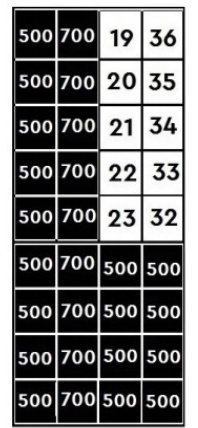

Case-3

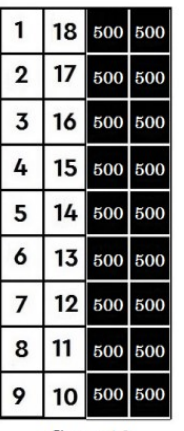

Case-10

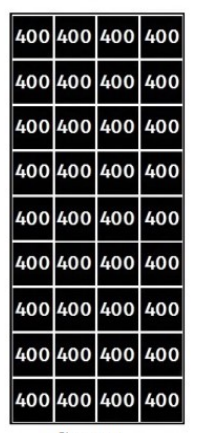

$\mathrm{Case}^{-4}$

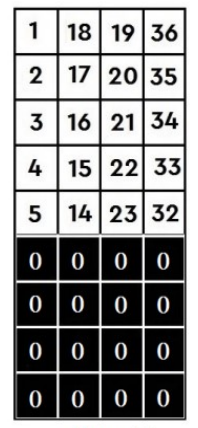

Case-11

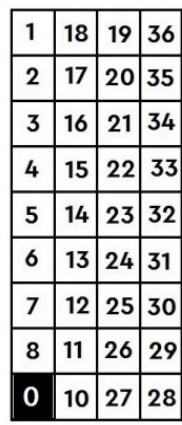

Case -5

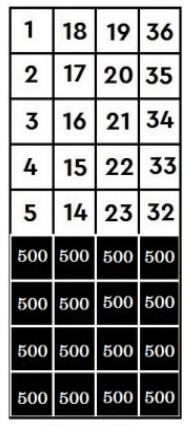

Case-12

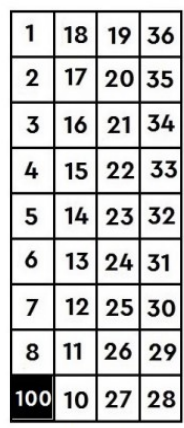

Case-6

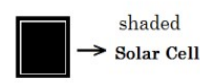

$0,400,500,700$ $\downarrow$

Irradiances in $\mathrm{W} / \mathrm{m} 2$

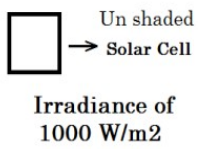

Figure 6. Different Cell level Shadings Considered in a 36 Full Cells Module

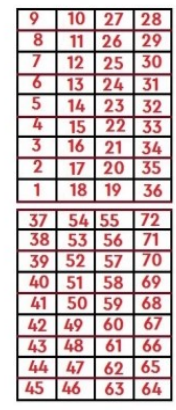

Case-U

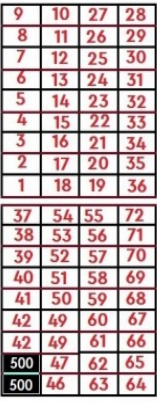

Case-7

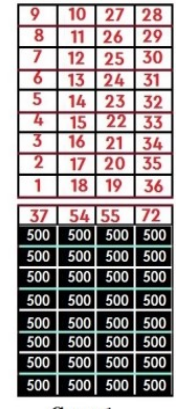

Case-1

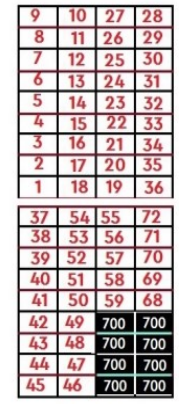

Case-8

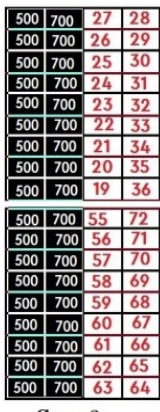

Case-2

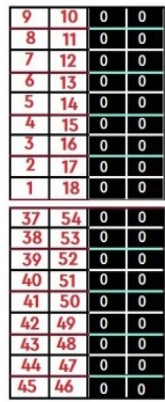

Case-9

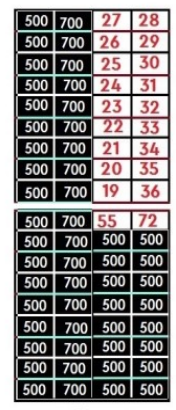

Case-3

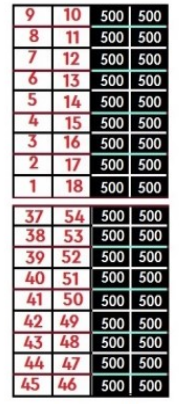

Case-10

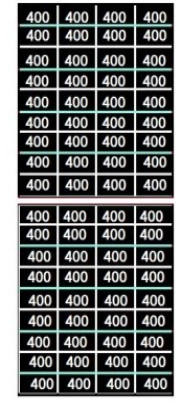

Case-4

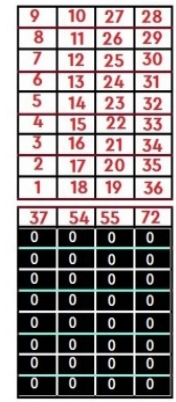

Case-11

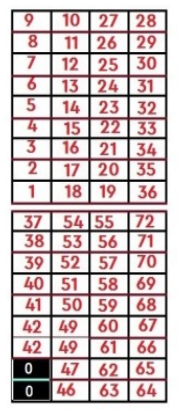

Case-5

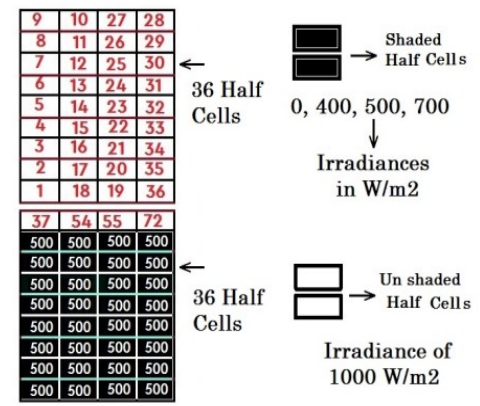

Case-12

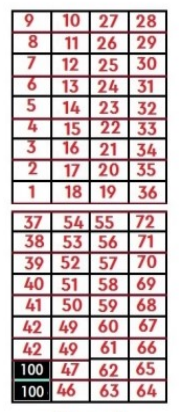

Case-6 $1000 \mathrm{~W} / \mathrm{m} 2$

Figure.7. Different Cell level Shadings Considered in a 72 Half Cells Module 


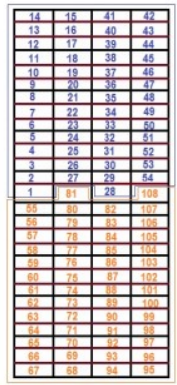

Case-U

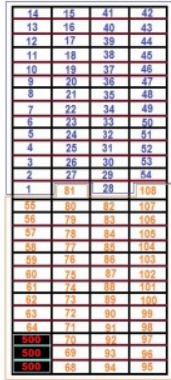

Case-7

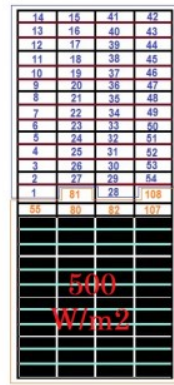

Case-1

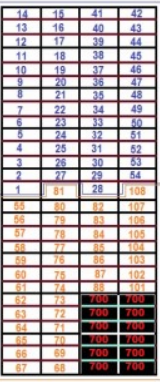

Case-8

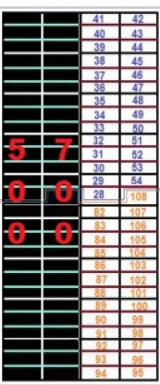

Case-2

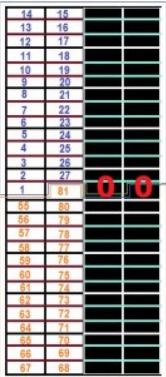

Case-9

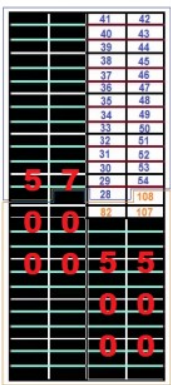

Case-3

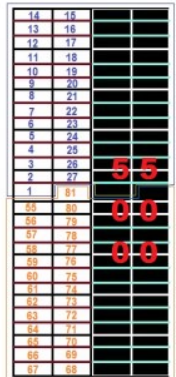

Case-10

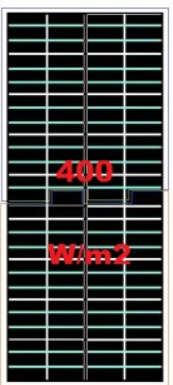

Case-4

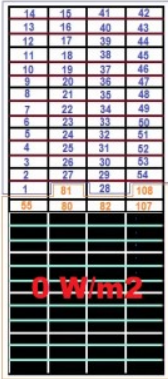

Case-11

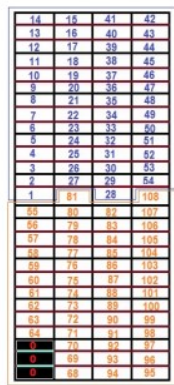

Case-5

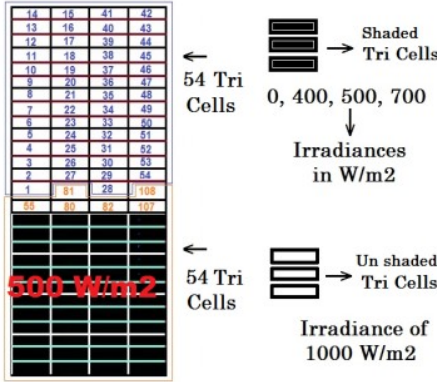

Case-12

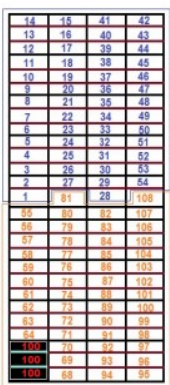

Case-6 $1000 \mathrm{~W} / \mathrm{m} 2$

Figure 8. Different Cell level Shadings Considered in a 108 Tri Cells Module

\subsection{MATLAB-Simulink model of PVM-CPT}

The MATLAB-Simulink model of a standard full cell module (FCM) for shading case-1( shown in Figure 6: case-1) is depicted in Figure 9. As illustrated in Figure 6, the 36 cells of an FCM are shaded in accordance with the shadings addressed at the cell levels. The PVM-CPT subsystem1 consists of conventional FCM and partial cell modules such as HCM and TCM, which is shown in Figure 9(a). The simulink model of PVMCPT Subsystem1 and Subsystem2 for a 36 cell FCM is illustrated in Figure 9(b). The terms $\mathrm{V}$, I and $\mathrm{P}$ are the solar PV module voltage(V), current(A) and power(W), respectively. The output (V-I and P-V) characteristics of PVM-CPT and FCM are obtained from V, I, and W.

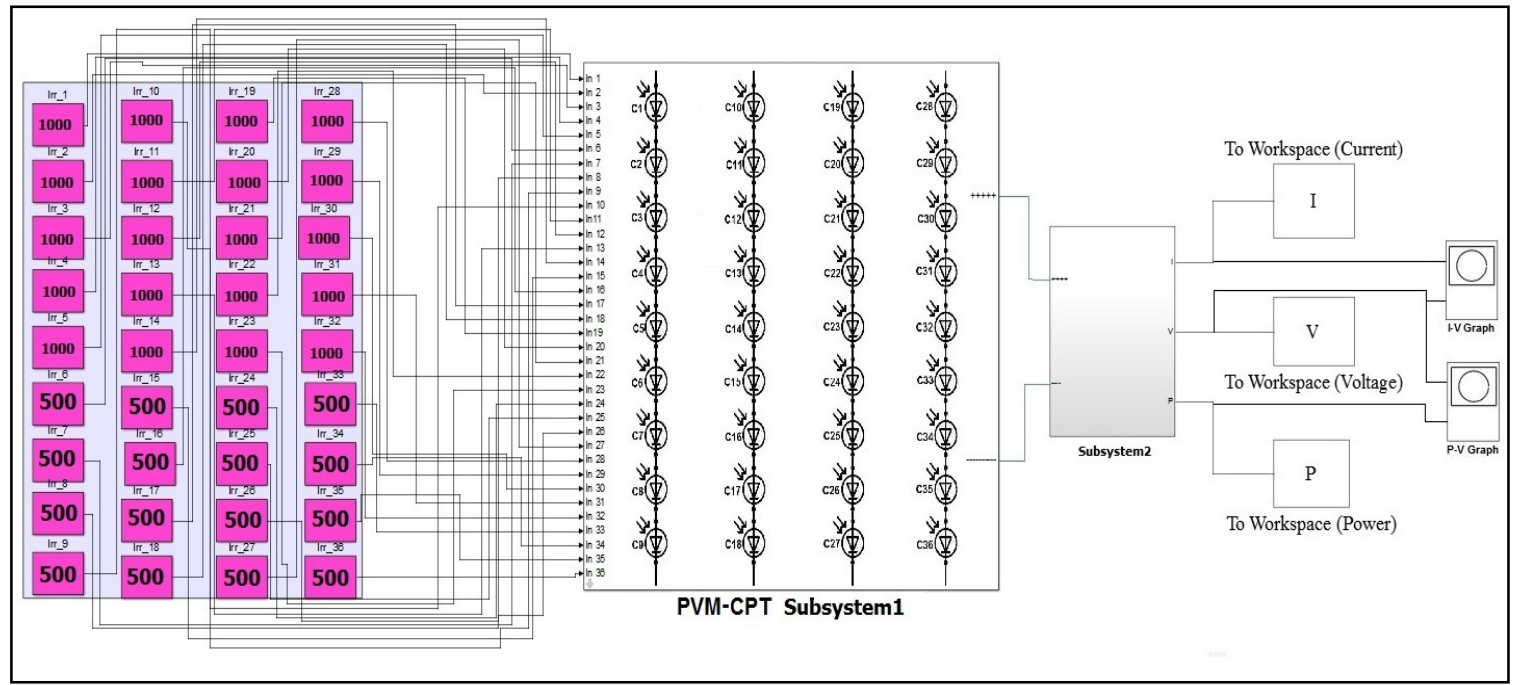

Figure 9(a). Matlab-Simulink model of a single PV Module with 36 Full Cells under Case-1 


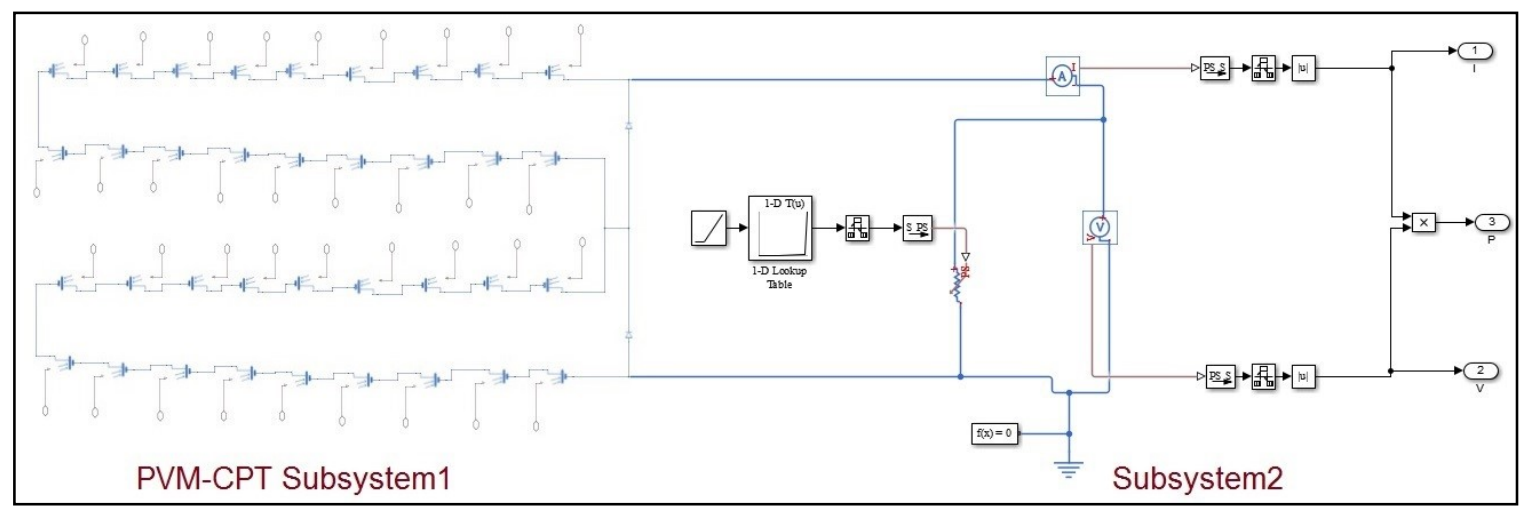

Figure 9(b). PVM-CPT Subsystem1 and Subsystem2 in Matlab-Simulink model of a single PV Module with 36 Full Cells under Case-1

\subsection{Results and Discussions}

In order to explain various shading cases, we first describe the case of uniform irradiance, (i.e., no shading) which means that all cells in a PV module get standard irradiance of $1000 \mathrm{~W} / \mathrm{m}^{2}$. In uniform irradiance case (case-U), the power output of single FCM, HCM and TCM is equal to $40.02 \mathrm{~W}, 40.75 \mathrm{~W}$, and $41 \mathrm{~W}$ respectively. The simulation results of a single standard FCM and PVM-CPT i.e., HCM, and TCM under different cell level shadings are presented in Tables 9,10 , and 11 respectively.

Table 9. Performance of Single Solar PV 36 Full Cells Module with 2 BD Under Cell Level Shadings

\begin{tabular}{|l|c|c|c|c|c|c|c|c|}
\hline \multirow{2}{*}{$\begin{array}{l}\text { Shading } \\
\text { Cases }\end{array}$} & \multicolumn{7}{|c|}{ Series Connected 36 Full Cells in a Single PV Module } \\
\cline { 2 - 10 } & $\mathrm{P}_{\max }(\mathrm{W})$ & $\mathrm{V}_{\max }(\mathrm{V})$ & $\mathrm{I}_{\mathrm{m}}(\mathrm{A})$ & $\mathrm{V}_{\text {oc }}(\mathrm{V})$ & $\mathrm{I}_{\mathrm{sc}}(\mathrm{A})$ & $\mathrm{ML}(\mathrm{W})$ & ML $(\%)$ & FF \\
\hline Case-U & 40.02 & 17.72 & 2.258 & 21.9 & 2.45 & 0 & 0 & 0.746 \\
\hline Case-1 & 21.94 & 18.62 & 1.178 & 21.47 & 1.225 & 18.08 & 45.18 & 0.834 \\
\hline Case-2 & 22.75 & 18.99 & 1.198 & 21.53 & 2.45 & 17.27 & 43.15 & 0.431 \\
\hline Case-3 & 21.43 & 18.25 & 1.174 & 21.31 & 1.225 & 18.59 & 46.45 & 0.821 \\
\hline Case-4 & 15.21 & 16.91 & 0.8993 & 20.62 & 0.98 & 24.81 & 61.99 & 0.753 \\
\hline Case-5 & 18.83 & 8.402 & 2.241 & 10.44 & 2.45 & 21.19 & 52.95 & 0.736 \\
\hline Case-6 & 18.84 & 8.348 & 2.256 & 21.8 & 2.45 & 21.18 & 52.92 & 0.353 \\
\hline Case-7 & 24.88 & 20.35 & 1.222 & 21.86 & 2.45 & 15.14 & 37.83 & 0.464 \\
\hline Case-8 & 32.59 & 19.19 & 1.698 & 21.84 & 2.45 & 7.43 & 18.57 & 0.609 \\
\hline Case-9 & 18.83 & 8.402 & 2.241 & 10.44 & 2.45 & 21.19 & 52.95 & 0.736 \\
\hline Case-10 & 21.64 & 18.4 & 1.176 & 21.42 & 2.45 & 18.38 & 45.93 & 0.412 \\
\hline Case-11 & 0 & 0 & 0 & 0 & 0 & 40.02 & 100.0 & 0 \\
\hline Case-12 & 21.94 & 18.62 & 1.178 & 21.47 & 1.225 & 18.08 & 45.18 & 0.834 \\
\hline
\end{tabular}

Table 10. Performance of Single Solar PV 72 Half Cells Module with 2 BD Under Cell Level Shadings

\begin{tabular}{|l|c|c|c|c|c|c|c|c|}
\hline \multirow{2}{*}{$\begin{array}{l}\text { Shading } \\
\text { Cases }\end{array}$} & \multicolumn{7}{|c|}{ Parallel Connected Two Half of $36 \mathrm{HC}$ in a Single PV modules } \\
\cline { 2 - 10 } & $\mathrm{P}_{\max }(\mathrm{W})$ & $\mathrm{V}_{\max }(\mathrm{V})$ & $\mathrm{I}_{\mathrm{m}}(\mathrm{A})$ & $\mathrm{V}_{\mathrm{oc}}(\mathrm{V})$ & $\mathrm{I}_{\mathrm{sc}}(\mathrm{A})$ & $\mathrm{ML}(\mathrm{W})$ & $\mathrm{ML}(\%)$ & FF \\
\hline Case-U & 40.75 & 18 & 2.264 & 21.9 & 2.45 & 40.75 & 0 & 0.7595 \\
\hline Case-1 & 30.31 & 17.8 & 1.703 & 21.52 & 1.838 & 10.44 & 25.62 & 0.7664 \\
\hline Case-2 & 22.96 & 19.13 & 1.2 & 21.53 & 2.45 & 17.79 & 43.66 & 0.4352 \\
\hline Case-3 & 22.44 & 18.77 & 1.195 & 21.35 & 1.837 & 18.31 & 44.93 & 0.5719 \\
\hline Case-4 & 15.32 & 17.08 & 0.8966 & 20.62 & 0.98 & 25.43 & 62.40 & 0.7573 \\
\hline
\end{tabular}




\begin{tabular}{|l|c|c|c|c|c|c|c|c|}
\hline Case-5 & 22.3 & 18.98 & 1.175 & 21.84 & 2.45 & 18.45 & 45.28 & 0.4168 \\
\hline Case-6 & 24.52 & 18.95 & 1.294 & 21.86 & 2.45 & 16.23 & 39.83 & 0.4579 \\
\hline Case-7 & 33.12 & 18.82 & 1.759 & 21.88 & 2.45 & 7.63 & 18.72 & 0.6175 \\
\hline Case-8 & 36.94 & 18.5 & 1.993 & 21.84 & 2.45 & 3.81 & 9.35 & 0.6891 \\
\hline Case-9 & 19.19 & 8.539 & 2.247 & 10.45 & 2.45 & 21.56 & 52.91 & 0.7494 \\
\hline Case-10 & 21.83 & 18.6 & 1.174 & 21.4 & 2.45 & 18.92 & 46.43 & 0.4165 \\
\hline Case-11 & 19.46 & 17.23 & 1.13 & 20.92 & 1.225 & 21.29 & 52.25 & 0.7597 \\
\hline Case-12 & 30.02 & 17.71 & 1.695 & 21.5 & 1.838 & 10.73 & 26.33 & 0.7596 \\
\hline
\end{tabular}

Table 11. Performance of Single Solar PV 108 Tri Cells Module with 2 BD Under Cell Level Shadings

\begin{tabular}{|l|c|c|c|c|c|c|c|c|}
\hline \multirow{2}{*}{$\begin{array}{l}\text { Shading } \\
\text { Cases }\end{array}$} & \multicolumn{7}{|c|}{ Parallel Connected Two Half of 54 TC in a Single PV modules } \\
\cline { 2 - 9 } & $\mathrm{P}_{\max }(\mathrm{W})$ & $\mathrm{V}_{\max }(\mathrm{V})$ & $\mathrm{I}_{\mathrm{m}}(\mathrm{A})$ & $\mathrm{V}_{\mathrm{oc}}(\mathrm{V})$ & $\mathrm{I}_{\mathrm{sc}}(\mathrm{A})$ & $\mathrm{ML}(\mathrm{W})$ & $\mathrm{ML}(\%)$ & FF \\
\hline Case-U & 41 & 27.09 & 1.513 & 32.82 & 1.633 & 0 & 0 & 0.7648 \\
\hline Case-1 & 30.45 & 26.75 & 1.139 & 32.3 & 1.225 & 10.55 & 25.73 & 0.7700 \\
\hline Case-2 & 23.02 & 28.67 & 0.8029 & 32.29 & 1.633 & 17.98 & 43.85 & 0.4366 \\
\hline Case-3 & 22.55 & 27.99 & 0.8036 & 32.02 & 1.225 & 18.5 & 45.12 & 0.5734 \\
\hline Case-4 & 15.56 & 25.61 & 0.5998 & 30.92 & 0.653 & 25.64 & 62.54 & 0.7608 \\
\hline Case-5 & 22.45 & 28.62 & 0.7823 & 32.77 & 1.633 & 18.61 & 45.39 & 0.4184 \\
\hline Case-6 & 24.83 & 28.55 & 0.8627 & 32.8 & 1.633 & 16.37 & 39.93 & 0.4598 \\
\hline Case-7 & 33.27 & 28.47 & 1.169 & 32.83 & 1.633 & 7.73 & 18.85 & 0.6208 \\
\hline Case-8 & 37.14 & 27.84 & 1.334 & 32.76 & 1.633 & 3.86 & 9.41 & 0.6942 \\
\hline Case-9 & 19.72 & 13.1 & 1.505 & 15.91 & 1.633 & 21.28 & 51.90 & 0.7588 \\
\hline Case-10 & 21.89 & 27.96 & 0.783 & 32.08 & 1.633 & 19.11 & 46.61 & 0.4179 \\
\hline Case-11 & 19.52 & 25.75 & 0.7581 & 31.38 & 0.816 & 21.48 & 52.39 & 0.7618 \\
\hline Case-12 & 30.16 & 26.62 & 1.133 & 32.23 & 1.225 & 10.84 & 26.44 & 0.7639 \\
\hline
\end{tabular}

From the simulation results, it can be concluded that:

- In uniform irradiance case (case-U), the power output of single FCM, HCM and TCM is equal to $40.02 \mathrm{~W}, 40.75 \mathrm{~W}$, and $41 \mathrm{~W}$ respectively.

- When compare to the conventional FCM, the power output of HCM and TCM is improved under the consideration of 12 cell level shading scenarios.

- In one cell shading case (case-5), the maximum power of FCM, HCM and TCM is $18.83 \mathrm{~W}, 22.3 \mathrm{~W}$ and $22.45 \mathrm{~W}$, respectively.

- Hotspot temperature and cell damage impact area in PVM-CPT are reduced due to smaller currents, so the risk of micro-crack propagation is less. Diode temperature also reduced.

\section{Proposed Static SD-TCTR Array with PVM-CPT}

Reconfiguration techniques are used to reduce the effects of partial shading on solar PV arrays. Reconfiguration is the process of changing the structure of an existing PV system, which can be accomplished either by modifying the physical positions i.e., physical relocation of PV modules or electrical connections i.e., electrical array reconfiguration. In order to decrease mismatch losses in partial shading conditions, reconfiguration techniques has been proposed by several authors[20-23] to reposition of PV modules inside the PV array. This work proposes a static reconfiguration technique to reduce mismatch losses and increase array power under different cell level shading conditions. The proposed shade dispersion based total cross tied reconfiguration 
(SD-TCTR) is a static reconfiguration method and is used to distribute the shading effectively throughout a PV array.

\subsection{General Rule for the Proposed Static SD-TCTR Array Connection}

The proposed Static Shade dispersion based Total Cross Tied reconfiguration (SD-TCTR) array arrangement adaptable to shading patterns of any size, i.e., row and column sizes can be odd or even. The rule for configuring a general solar array can be defined as:

$n_{r c}$, Where $\left\{\begin{array}{cc}r=\text { Row number } & (r=1,2,3,4, \ldots) \\ c=\text { Column number } & (j=1,2,3,4, \ldots)\end{array}\right.$

where $\mathrm{n}_{\mathrm{rc}}$ is written for the $\mathrm{n}^{\text {th }}$ element of the $\mathrm{r}^{\text {th }}$ row and $\mathrm{c}^{\text {th }}$ column of a shading pattern. The following equations can be considered for determining the logic number in a column: Where $r_{m}$ is the maximum number of rows, and $c_{m}$ is the maximum number of columns in a $r_{m} x_{m}$ solar PV array.

$$
\begin{aligned}
& c=\left\{\begin{array}{cc}
c & \text { if } r=1 \\
c+(r-1) \cdot \text { floor }\left(\frac{2 \cdot c_{m}}{r_{m}}\right), & r>1 \text { and } c_{m} \text { is Even } \\
c+(r-1) . \text { ceil }\left(\frac{2 \cdot c_{m}}{r_{m}}\right), & r>1 \text { and } c_{m} \text { is Odd }
\end{array}\right. \\
& \text { if } c<c_{m}, \quad c=c \\
& \text { else } c=c-c_{m}
\end{aligned}
$$

If any number is repeated in a column, just add 1 to the corresponding column, i.e., $\mathrm{c}=\mathrm{c}_{0}+1$ ( $\mathrm{c}_{0}$ is the repeated column number). Alternatively, create a column with the same number(c).

\subsection{Formation of Proposed Static SD-TCTR Array Connection [13]}

The primary objective of an Static SD-TCTR design is to distribute shadows throughout the array under shadings by arranging a $r \times c$ array column location with the numbers 1 to $\mathrm{c}$ as illustrated in Figure 10.The proposed Static SD-TCTR array is implemented using Number Logic (NL) method and this method is developed for $r=$ odd or even for the column location arrangement of the $\boldsymbol{r} \times \boldsymbol{c}$ solar PV array. A unique solution is obtained by adding 1 to the preceding logic number in a specific column (c) and row (r) of a solar PV array in order to avoid the numbers repeating in that column and row. The proposed number logic method is applied for any array size, which is used in this paper for $3 \times 4,4 \times 3$, and $4 \times 4$ solar PV arrays shown in Figure 10 . The 1 st number in the box represents a logic number, and the 2 nd number denotes the column number. The row and column positions in a $4 \times 4$ array are arranging with the numbers 1 to 4 in the proposed arrangement, as shown in Figure 10(a). R1, R2, R3 and R4 represent the rows numbers, while $\mathrm{C} 1, \mathrm{C} 2, \mathrm{C} 3$ and $\mathrm{C} 4$ represents the column numbers. 


\begin{tabular}{|l|l|l|l|l|}
\hline \multicolumn{2}{c}{} & \multicolumn{2}{c}{ C1 } & \multicolumn{2}{c}{ C2 } & \multicolumn{2}{c}{ C3 } & \multicolumn{1}{c}{ C4 } \\
\cline { 2 - 5 } R1 & 11 & $\mathbf{2 2}$ & $\mathbf{3 3}$ & $\mathbf{4 4}$ \\
\cline { 2 - 5 } R2 & $\mathbf{3 1}$ & $\mathbf{4 2}$ & $\mathbf{1 3}$ & $\mathbf{2 4}$ \\
\cline { 2 - 5 } R3 & $\mathbf{2 1}$ & $\mathbf{3 2}$ & $\mathbf{4 3}$ & $\mathbf{1 4}$ \\
\cline { 2 - 5 } R4 & $\mathbf{4 1}$ & $\mathbf{1 2}$ & $\mathbf{2 3}$ & $\mathbf{3 4}$ \\
\cline { 2 - 5 } & & & &
\end{tabular}

(a) $4 \times 4$ Array modules with Proposed NL method

\begin{tabular}{l|l|l|l|}
\multicolumn{1}{c}{} & \multicolumn{1}{c}{$\mathrm{C} 1$} & \multicolumn{1}{c}{$\mathrm{C} 2$} & \multicolumn{1}{c}{$\mathrm{C}$} \\
\cline { 2 - 4 } R1 & 11 & $\mathbf{2 2}$ & $\mathbf{3 3}$ \\
\cline { 2 - 4 } R2 & $\mathbf{3 1}$ & $\mathbf{4 2}$ & $\mathbf{1 3}$ \\
\cline { 2 - 4 } R3 & $\mathbf{2 1}$ & $\mathbf{3 2}$ & $\mathbf{4 3}$ \\
\cline { 2 - 4 } R4 & $\mathbf{4 1}$ & $\mathbf{1 2}$ & $\mathbf{2 3}$ \\
\cline { 2 - 4 } & & &
\end{tabular}

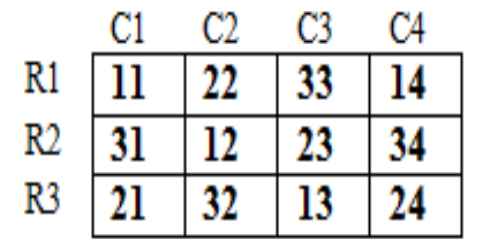

(b) $4 \times 3$ Array modules with Proposed NL method
(C) $3 \times 4$ Array modules with Proposed NL method

Figure 10. SD-TCTR arrangement of $4 \times 4,4 \times 3$ and $3 \times 4$ arrays with Number Logic(NL) method

4.3 Performance Investigation of $3 \times 4,4 \times 3$ and $4 \times 4$ SPV Arrays with Cell Level Shading Cell Level Shading (CLS) Conditions

In order to investigate the performance of PVM-CPT, we have conducted the tests on $3 \times 4,4 \times 3$, and $4 \times 4$ solar PV arrays under cell level shading (CLS) conditions. In this section, total four shading cases mainly Short Narrow (SN), Short Wide (SW), Long Narrow (LN), Long Wide (LW) type under cell level are considered for analyzing the performance of solar PV arrays. Figures 11 and 12 illustrate the various partial shading conditions that were investigated in this study. Figure 11 illustrates the $3 \times 4,4 \times 3$, and $4 \times 4$ SPV arrays with different cell level partial shading cases such as SW, SN, LW, LN (case: 1 to case: 4 ) and Figure 12 represents the shaded cells positions in PVM-CPT of different PV arrays.

\begin{tabular}{|c|c|c|c|c|c|c|c|c|c|c|c|c|c|c|c|}
\hline 1000 & 1000 & 1000 & 1000 & 1000 & 1000 & 1000 & 1000 & LW1 & 1000 & 1000 & 1000 & 1000 & 1000 & 1000 & 1000 \\
\hline 1000 & 1000 & 1000 & 1000 & SN & SN & 1000 & 1000 & LW1 & 1000 & 1000 & 1000 & $\mathrm{LN}$ & $\mathrm{LN}$ & $\mathrm{LN}$ & 1000 \\
\hline SW & SW & SW & SW & SN & SN & 1000 & 1000 & LW2 & LW3 & LW3 & LW3 & $\mathrm{LN}$ & $\mathrm{LN}$ & $\mathrm{LN}$ & 1000 \\
\hline \multicolumn{4}{|c|}{$\begin{array}{l}\text { Case-1: } 3 \times 4 \text { Array with } \\
\text { SW Shading }\end{array}$} & \multicolumn{4}{|c|}{$\begin{array}{l}\text { Case-2: } 3 \times 4 \text { Array with } \\
\text { SN Shading }\end{array}$} & \multicolumn{4}{|c|}{$\begin{array}{l}\text { Case-3:3x4 Array with } \\
\text { LW Shading }\end{array}$} & \multicolumn{4}{|c|}{$\begin{array}{l}\text { Case-4: } 3 \times 4 \text { Array with } \\
\text { LN Shading }\end{array}$} \\
\hline 1000 & 1000 & \multicolumn{2}{|c|}{1000} & 1000 & 1000 & \multicolumn{2}{|l|}{1000} & LW1 & 1000 & 1000 & & 1000 & 1000 & \multicolumn{2}{|c|}{1000} \\
\hline 1000 & 1000 & \multicolumn{2}{|c|}{1000} & 1000 & 1000 & \multicolumn{2}{|l|}{1000} & LW1 & 1000 & 1000 & & 1000 & 1000 & \multicolumn{2}{|c|}{1000} \\
\hline 1000 & 1000 & \multicolumn{2}{|c|}{1000} & SN & SN & \multicolumn{2}{|l|}{1000} & LW1 & 1000 & 1000 & & $\mathrm{LN}$ & LN & \multicolumn{2}{|c|}{$\mathrm{LN}$} \\
\hline SW & SW & \multicolumn{2}{|c|}{ SW } & SN & $\mathrm{SN}$ & \multicolumn{2}{|l|}{1000} & LW2 & LW3 & LW3 & & $\mathrm{LN}$ & LN & \multicolumn{2}{|l|}{$\mathrm{LN}$} \\
\hline \multicolumn{4}{|c|}{$\begin{array}{l}\text { Case-1:4x3 Array with } \\
\text { SW Shading }\end{array}$} & \multicolumn{4}{|c|}{$\begin{array}{l}\text { Case-2: } 4 \times 3 \text { Array with } \\
\text { SN Shading }\end{array}$} & \multicolumn{4}{|c|}{$\begin{array}{l}\text { Case-3: } 4 \times 3 \text { Array with } \\
\text { LW Shading }\end{array}$} & \multicolumn{4}{|c|}{$\begin{array}{l}\text { Case-4: } 4 \times 3 \text { Array with } \\
\text { LN Shading }\end{array}$} \\
\hline 1000 & 1000 & 1000 & 1000 & 1000 & 1000 & 1000 & 1000 & LW1 & 1000 & 1000 & 1000 & 1000 & 1000 & 1000 & 1000 \\
\hline 1000 & 1000 & 1000 & 1000 & 1000 & 1000 & 1000 & 1000 & LW1 & 1000 & 1000 & 1000 & 1000 & 1000 & 1000 & 1000 \\
\hline 1000 & 1000 & 1000 & 1000 & SN & SN & 1000 & 1000 & LW1 & 1000 & 1000 & 1000 & $\mathrm{LN}$ & $\mathrm{LN}$ & $\mathrm{LN}$ & 1000 \\
\hline SW & SW & SW & SW & $\mathrm{SN}$ & SN & 1000 & 1000 & LW2 & LW3 & LW3 & LW3 & $\mathrm{LN}$ & $\mathrm{LN}$ & $\mathrm{LN}$ & 1000 \\
\hline Case-1:4x4 Array with & $\begin{array}{l}\text { se-1:4x } \\
\text { SW }\end{array}$ & $\begin{array}{l}\text { Array } \\
\text { hading }\end{array}$ & & \multicolumn{3}{|c|}{ Case-2: $4 \times 4$ Array with } & & \multicolumn{4}{|c|}{ Case-3: $4 \times 4$ Array with } & \multicolumn{4}{|c|}{$\begin{array}{c}\text { Case-4: } 4 \times 4 \text { Array with } \\
\text { LN Shading }\end{array}$} \\
\hline
\end{tabular}

Figure 11. Illustration of solar irradiance levels in $3 \times 4,4 \times 3$ and $4 \times 4$ SPV arrays under SW,SN,LN and LW shadings in cell level 


\begin{tabular}{|c|c|c|c|c|c|c|c|c|c|c|c|}
\hline 1000 & 1000 & 1000 & 1000 & 600 & 600 & 600 & 600 & 450 & 1000 & 1000 & 1000 \\
\hline 1000 & 1000 & 1000 & 1000 & 600 & 600 & 600 & 600 & 450 & 1000 & 1000 & 1000 \\
\hline 1000 & 1000 & 1000 & 1000 & 600 & 600 & 600 & 600 & 450 & 1000 & 1000 & 1000 \\
\hline 1000 & 1000 & 1000 & 1000 & 600 & 600 & 600 & 600 & 450 & 1000 & 1000 & 1000 \\
\hline 1000 & 1000 & 1000 & 1000 & 600 & 600 & 600 & 600 & 450 & 1000 & 1000 & 1000 \\
\hline 350 & 350 & 350 & 350 & 1000 & 1000 & 1000 & 1000 & 450 & 1000 & 1000 & 1000 \\
\hline 350 & 350 & 350 & 350 & 1000 & 1000 & 1000 & 1000 & 450 & 1000 & 1000 & 1000 \\
\hline 350 & 350 & 350 & 350 & 1000 & 1000 & 1000 & 1000 & 450 & 1000 & 1000 & 1000 \\
\hline 350 & 350 & 350 & 350 & 1000 & 1000 & 1000 & 1000 & 450 & 1000 & 1000 & 1000 \\
\hline \multicolumn{4}{|c|}{ SW: Shaded Cells position } & \multicolumn{4}{|c|}{ SN: Shaded Cells position } & \multicolumn{4}{|c|}{ LN: Shaded Cells position } \\
\hline 700 & 700 & 1000 & 1000 & 700 & 700 & 1000 & 1000 & 1000 & 1000 & 1000 & 1000 \\
\hline 700 & 700 & 1000 & 1000 & 700 & 700 & 1000 & 1000 & 1000 & 1000 & 1000 & 1000 \\
\hline 700 & 700 & 1000 & 1000 & 700 & 700 & 1000 & 1000 & 1000 & 1000 & 1000 & 1000 \\
\hline 700 & 700 & 1000 & 1000 & 700 & 700 & 1000 & 1000 & 1000 & 1000 & 1000 & 1000 \\
\hline 700 & 700 & 1000 & 1000 & 700 & 700 & 1000 & 1000 & 1000 & 1000 & 1000 & 1000 \\
\hline 700 & 700 & 1000 & 1000 & 700 & 700 & 500 & 500 & 500 & 500 & 500 & 500 \\
\hline 700 & 700 & 1000 & 1000 & 700 & 700 & 500 & 500 & 500 & 500 & 500 & 500 \\
\hline 700 & 700 & 1000 & 1000 & 700 & 700 & 500 & 500 & 500 & 500 & 500 & 500 \\
\hline 700 & 700 & 1000 & 1000 & 700 & 700 & 500 & 500 & 500 & 500 & 500 & 500 \\
\hline \multicolumn{4}{|c|}{ Cells position } & \multicolumn{4}{|c|}{ LW2: Shaded Cells position } & \multicolumn{4}{|c|}{ LW3: Shaded Cells position } \\
\hline
\end{tabular}

Figure 12. Number of Cells shaded in a single PVM-CPT used in $3 \times 4,4 \times 3$ and $4 \times 4$ solar PV arrays under SW, SN, LN and LW shading cases

\subsection{Solar PV Arrays with TCT and Static SD-TCTR arrangements}

The solar PV modules are connected in several ways, there are series-parallel (SP), Series (S), total cross tied (TCT), bridge link (BL) and honey comb (HC) type of configurations. In this paper, only SP and TCT configurations are considered for simulation and compared with static SD-TCTR array under different cell level shading cases. In Figure 13: Cases 1(a), 2(a), 3(a), and 4(a) represent the shaded modules in TCT configuration. In Figure-14: Cases 1(b), 2(b), 3(b), and 4(b) represent the shaded modules in static SD-TCTR arrangement using proposed NL method discussed in the above section. In Figure 15: Cases 1(c), 2(c), 3(c), and 4(c) represent the shade dispersion of modules in TCT configuration for $3 \times 4,4 \times 3$ and $4 \times 4$ arrays. Partial shading cases $1,2,3$ and 4 are short wide (SW), long-wide (LW), short narrow(SN), and long narrow(LN) shadings in cell level, respectively.

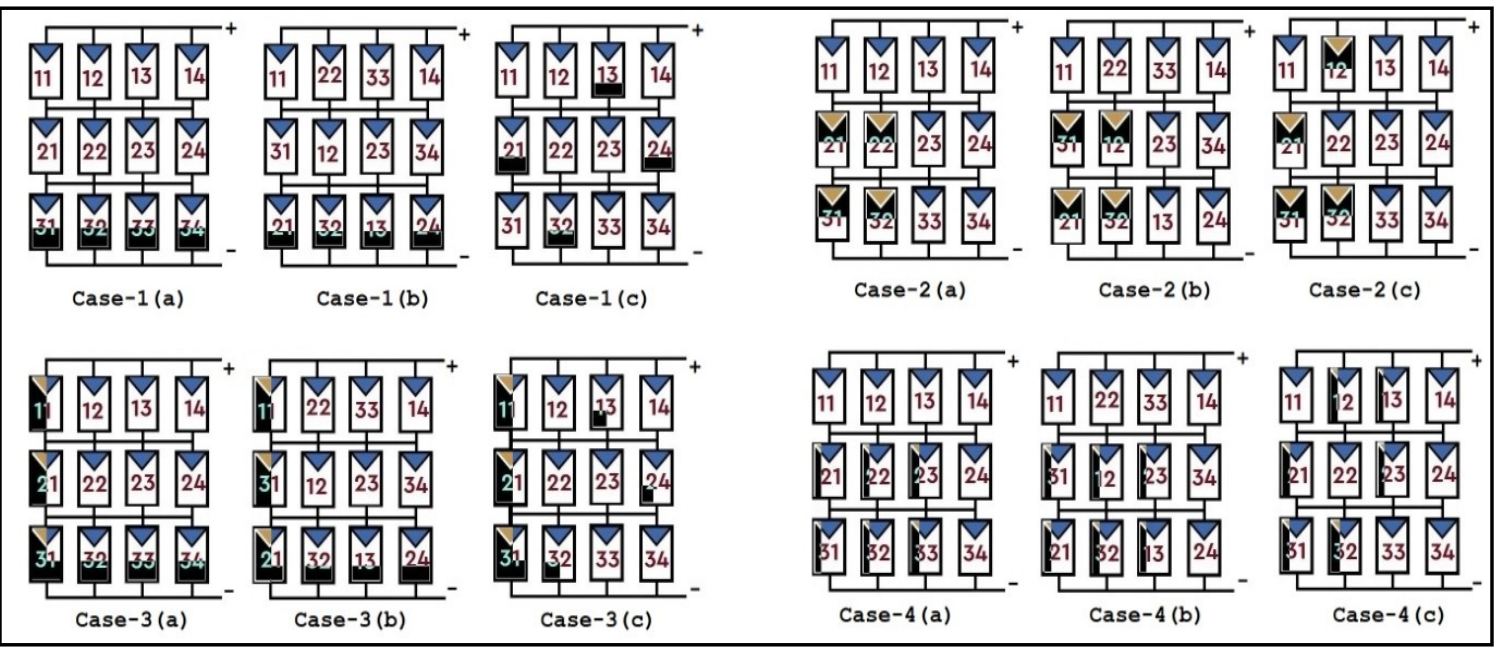

Figure 13. 3x4 SPV Array with TCT and SD-TCTR arrangements under 4 shading cases 


\begin{tabular}{|c|c|c|c|c|c|}
\hline 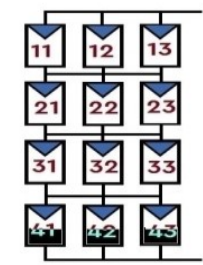 & 112 33 & 闻用 & 19 & 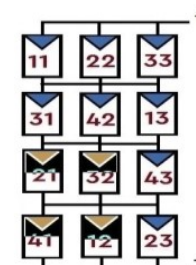 & 1102013 \\
\hline Case-1(a) & Case-1(b) & Case-1(c) & Case-2(a) & Case-2(b) & Case-2(c) \\
\hline 11. 12 & 4122 & 113 & 田问闻 & 11 22 33 & 11 \\
\hline 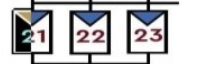 & 33142 & 22122 & 2122 & 314213 & 21 22 核3 \\
\hline (31) $32 \sqrt{33}$ & 2132 & $3 0 \longdiv { 3 2 } 3$ & 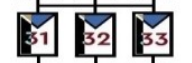 & 212 & 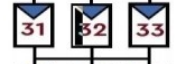 \\
\hline & 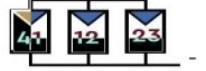 & 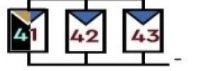 & 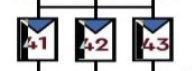 & 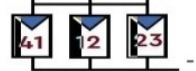 & 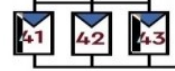 \\
\hline Case-3(a) & Case-3(b) & Case-3(c) & Case-4(a) & Case-4(b) & Case-4(c) \\
\hline
\end{tabular}

Figure 14. 4x3 SPV Array with TCT and SD-TCTR arrangements under 4 shading cases

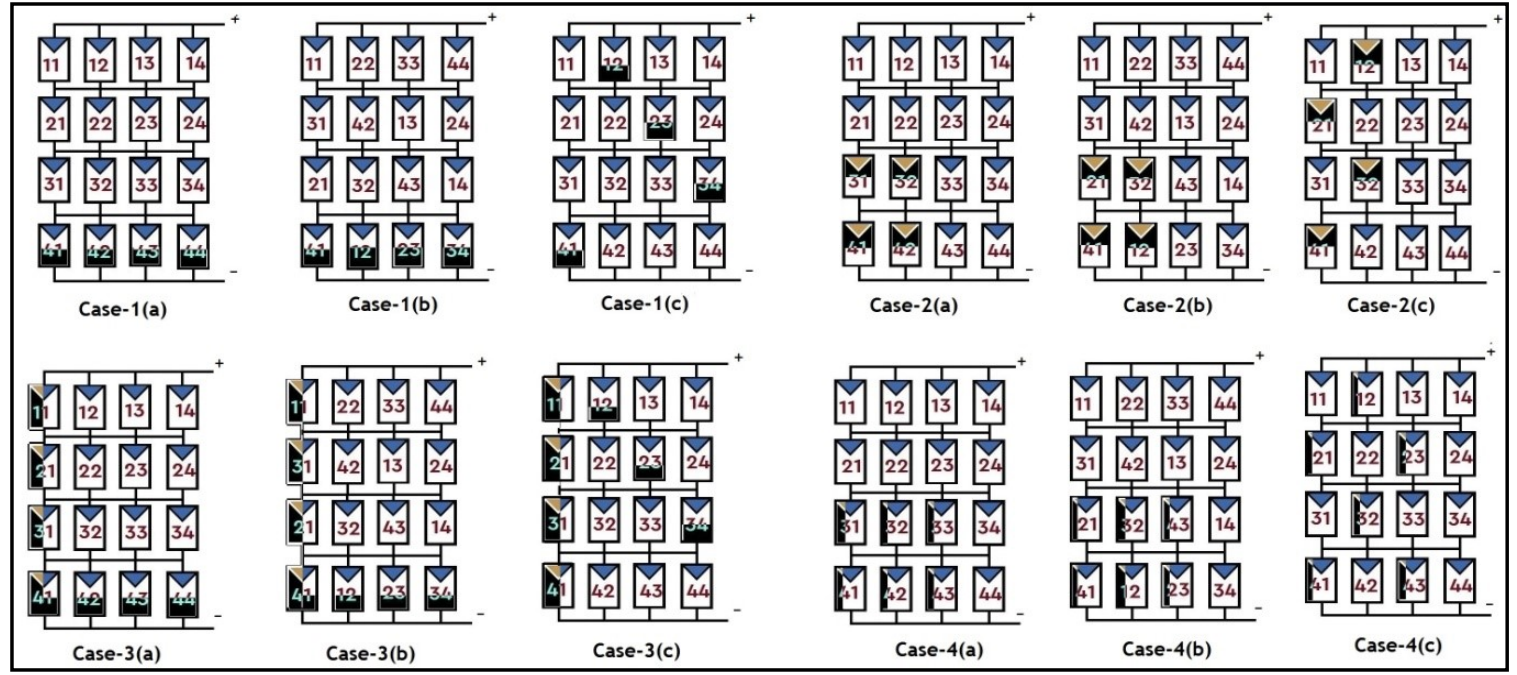

Figure 15. 4x4 SPV Array with TCT and SD-TCTR arrangements under 4 shading cases

\subsection{MATLAB/Simulink model of SP, TCT and static SD-TCTR Array Connections}

The developed $40 \mathrm{~W}$ solar PV modules using number of solar cells, which are connected in series-parallel (SP), total-cross-tied (TCT) and proposed static SD-TCTR connections, are modeled and simulated in MATLAB/Simulink software. Figure 16 shows the Simulink model of $3 \times 4$ static SD-TCTR array with CPT based modules (PVMCPT) under shading case -4 . Each solar PV module in a $3 \times 4$ array is PVM-CPT and connected in static SD-TCTR array connection (discussed in previous section). The static SD-TCTR array with PVM-CPT is modeled under Short Narrow (SN), Long Narrow (LN), Short Wide (SW), and Long Wide (LW) type in cell level shadings. The power output of each PVM-CPT under uniform case- $\mathrm{U}$ is approximately $40.75 \mathrm{~W}$, and $41 \mathrm{~W}$. The different array sizes $3 \times 4,4 \times 3$ and $4 \times 4$ are modeled and simulated under cell level shadings in MATLAB/Simulink software. Moreover, all shading cases are carried out at constant temperature of $25^{\circ} \mathrm{C}$. The standard FCM, HCM and TCM type PV modules are used to develop $3 \times 4,4 \times 3$ and $4 \times 4$ array configurations. 


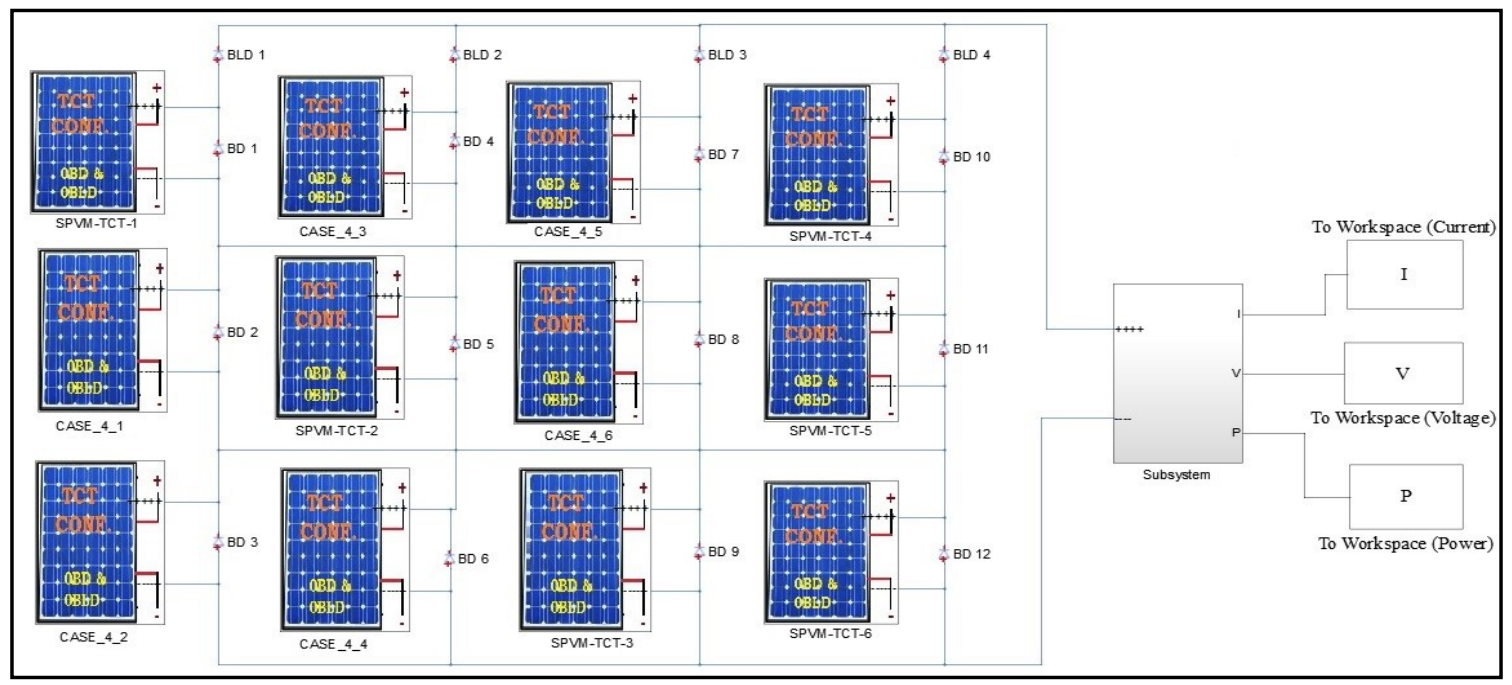

Figure 16. Simulink model of a 3x4 Static SD-TCTR array with FCM,HCM, and TCM 4.6 Results and Performance Evaluation of Proposed Static SDTCTR with PVMCPT

The obtained global maximum powers of SP and TCT configuration with FCM (Full cell module), HCM (Half cell module), TCM (Tri cell module) and proposed static SD-TCTR array with PVM-CPT under different cell level shadings(CLS) for an array sizes of $3 \times 4,4 \times 3$ and $4 \times 4$ are tabulated in Tables 12,13 and 14 , respectively. SP_FCM represents the series parallel configuration with FCM, TCT_FCM represents the Total Cross Tied configuration with FCM, SP_HCM represents the series parallel configuration with HCM, TCT_HCM represents the Total Cross Tied configuration with HCM, SP_TCM represents the series parallel configuration with TCM, and TCT_TCM represents the Total Cross Tied configuration with TCM. Prop_FCM represents the proposed static SD-TCTR array with FCM, Prop_HCM represents the proposed static SD-TCTR array with HCM, Prop_TCM represents the proposed static SD-TCTR array with TCM.

Table 12. Comparison of FCM, HCM, and TCM with 2 BD's under CLS for a $3 \times 4$ array

\begin{tabular}{|c|c|c|c|c|c|c|c|c|c|c|}
\hline \multirow{3}{*}{ CASES } & \multicolumn{10}{|c|}{ Global maximum powers of a $3 \times 4$ array in Watts } \\
\hline & \multicolumn{3}{|c|}{$3 \times 4$ array with FCM } & \multicolumn{3}{|c|}{$3 \times 4$ array with $\mathrm{HCM}$} & \multicolumn{3}{|c|}{$3 \times 4$ array with TCM } & \multirow[b]{2}{*}{ BEST } \\
\hline & $\begin{array}{l}\text { SP } \\
\text { FCM }\end{array}$ & $\begin{array}{l}\text { TCT } \\
\text { FCM }\end{array}$ & $\begin{array}{l}\text { Prop } \\
\text { FCM }\end{array}$ & $\begin{array}{l}\text { SP } \\
\text { TCM }\end{array}$ & $\begin{array}{l}\text { TCT } \\
\text { TCM }\end{array}$ & $\begin{array}{l}\text { Prop } \\
\text { HCM }\end{array}$ & $\begin{array}{l}\text { SP } \\
\text { TCM }\end{array}$ & $\begin{array}{l}\text { TCT } \\
\text { TCM }\end{array}$ & $\begin{array}{l}\text { Prop } \\
\text { TCM }\end{array}$ & \\
\hline Case-U & 475.5 & 475.5 & 475.5 & 484.3 & 484.3 & 484.3 & $\begin{array}{l}488 . \\
8\end{array}$ & $\begin{array}{l}488 . \\
8\end{array}$ & 488.8 & Prop TCM \\
\hline Case-1 & 306.2 & 306.2 & 352.3 & 361.8 & 361.8 & 423.7 & $\begin{array}{l}364 . \\
3\end{array}$ & $\begin{array}{l}364 . \\
3\end{array}$ & 427.4 & Prop_TCM \\
\hline Case-2 & 393.2 & 401.6 & 408.3 & 396.2 & 404 & 411.8 & $\begin{array}{l}399 . \\
5\end{array}$ & $\begin{array}{l}407 . \\
3\end{array}$ & 415.3 & Prop_TCM \\
\hline Case-3 & 275 & 281 & 366.6 & 365.7 & 365.5 & 397.5 & $\begin{array}{l}368 . \\
5\end{array}$ & $\begin{array}{l}368 . \\
2\end{array}$ & 401 & Prop_TCM \\
\hline Case-4 & 313.7 & 310 & 355.3 & 319.3 & 315.7 & 361.4 & 326 & $\begin{array}{l}322 . \\
4\end{array}$ & 364.6 & Prop_TCM \\
\hline
\end{tabular}


Table 13. Comparison of FCM, HCM, and TCM with 2 BD's under CLS for a $4 \times 3$ array

\begin{tabular}{|c|c|c|c|c|c|c|c|c|c|c|}
\hline \multirow{3}{*}{ CASES } & \multicolumn{10}{|c|}{ Global maximum powers of a $4 \times 3$ array in Watts } \\
\hline & \multicolumn{3}{|c|}{$4 \times 3$ array with FCM } & \multicolumn{3}{|c|}{$4 \times 3$ array with $\mathrm{HCM}$} & \multicolumn{3}{|c|}{$4 \times 3$ array with TCM } & \multirow[b]{2}{*}{ BEST } \\
\hline & $\begin{array}{l}\mathrm{SP} \\
\mathrm{FCM}\end{array}$ & $\begin{array}{l}\text { TCT } \\
\text { FCM }\end{array}$ & $\begin{array}{l}\text { Prop } \\
\text { FCM }\end{array}$ & $\begin{array}{l}\mathrm{SP} \\
\mathrm{TCM}\end{array}$ & $\begin{array}{l}\text { TCT } \\
\text { TCM }\end{array}$ & $\begin{array}{l}\text { Prop } \\
\text { HCM }\end{array}$ & $\begin{array}{l}\mathrm{SP} \\
\mathrm{TCM}\end{array}$ & $\begin{array}{l}\text { TCT } \\
\text { TCM }\end{array}$ & $\begin{array}{l}\text { Prop } \\
\text { TCM }\end{array}$ & \\
\hline Case-U & 476.7 & 476.7 & 476.7 & 485.5 & 485.5 & 485.5 & $\begin{array}{l}489 . \\
5\end{array}$ & $\begin{array}{l}489 . \\
5\end{array}$ & 489.5 & Prop_TCM \\
\hline Case-1 & 349.1 & 349.7 & 387.8 & 369.2 & 369.2 & 439.6 & $\begin{array}{l}371 . \\
3\end{array}$ & $\begin{array}{l}371 . \\
3\end{array}$ & 443.1 & Prop_TCM \\
\hline Case-2 & 370.4 & 382.3 & 418.7 & 465.9 & 383 & 422.7 & 375 & $\begin{array}{l}385 . \\
6\end{array}$ & 434.5 & Prop_TCM \\
\hline Case-3 & 296.9 & 296.9 & 347.1 & 360.5 & 360.4 & 383.4 & $\begin{array}{l}362 . \\
8\end{array}$ & $\begin{array}{l}362 . \\
8\end{array}$ & 386.3 & Prop_TCM \\
\hline Case-4 & 349.7 & 349.7 & 332.2 & 356.3 & 356.3 & 337.1 & 362 & 362 & 339.4 & $\begin{array}{r}S P \_T C M \text { or } \\
T C T \_T C M \\
\end{array}$ \\
\hline
\end{tabular}

Table 14. Comparison of FCM, HCM, and TCM with 2 BD's under CLS for a $4 \times 4$ array

\begin{tabular}{|c|c|c|c|c|c|c|c|c|c|c|}
\hline \multirow{3}{*}{ CASES } & \multicolumn{10}{|c|}{ Global maximum powers of a $4 \times 4$ array in Watts } \\
\hline & \multicolumn{3}{|c|}{$4 \times 4$ array with FCM } & \multicolumn{3}{|c|}{$4 \times 4$ array with $\mathrm{HCM}$} & \multicolumn{3}{|c|}{$4 \times 4$ array with TCM } & \multirow[b]{2}{*}{ BEST } \\
\hline & $\begin{array}{l}\text { SP } \\
\text { FCM }\end{array}$ & $\begin{array}{l}\text { TCT } \\
\text { FCM }\end{array}$ & $\begin{array}{l}\text { Prop } \\
\text { FCM }\end{array}$ & $\begin{array}{l}\text { SP } \\
\text { TCM }\end{array}$ & $\begin{array}{l}\text { TCT } \\
\text { TCM }\end{array}$ & $\begin{array}{l}\text { Prop } \\
\text { HCM }\end{array}$ & $\begin{array}{l}\text { SP } \\
\text { TCM }\end{array}$ & $\begin{array}{l}\text { TCT } \\
\text { TCM }\end{array}$ & $\begin{array}{l}\text { Prop }_{-} \\
\text {TCM }\end{array}$ & \\
\hline Case-U & 635.6 & 635.6 & 635.6 & 647.3 & 647.3 & 647.3 & $\begin{array}{l}652 . \\
8\end{array}$ & $\begin{array}{l}652 . \\
8\end{array}$ & 652.8 & Prop TCM \\
\hline Case-1 & 466.2 & 466.2 & 536.6 & 492.3 & 492.3 & 593 & $\begin{array}{l}494 . \\
8\end{array}$ & $\begin{array}{l}494 . \\
8 \\
\end{array}$ & 597.8 & Prop_TCM \\
\hline Case-2 & 527.4 & 546.6 & 577.6 & 556.4 & 550.6 & 584.6 & $\begin{array}{l}537 . \\
3\end{array}$ & $\begin{array}{l}555 . \\
7\end{array}$ & 589.3 & Prop_TCM \\
\hline Case-3 & 413.3 & 413.3 & 499.1 & 495.5 & 495.4 & 538.6 & $\begin{array}{l}498 . \\
4\end{array}$ & $\begin{array}{l}498 . \\
3\end{array}$ & 542.8 & Prop_TCM \\
\hline Case-4 & 477.2 & 470.1 & 495.1 & 485.7 & 478.7 & 503.1 & $\begin{array}{l}493 . \\
3\end{array}$ & $\begin{array}{l}486 . \\
4\end{array}$ & 506.8 & Prop_TCM \\
\hline
\end{tabular}

The analysis results so far have demonstrated what advantages are available in terms of power output and least mismatch power loss, when using half-cells and tri-cells instead of full-size cells (FC) for solar PV modules. Figures 17, 18 and 19 represent the global maximum powers of $3 \times 4,4 \times 3$ and $4 \times 4$ solar PV arrays, respectively.

From the above obtained results it can be concluded that:

- The amount of power that a $3 \times 4,4 \times 3$ and $4 \times 4$ array can produce under uniform irradiance case- $\mathrm{U}$ is $475.5 \mathrm{~W}, 476.7 \mathrm{~W}$ and $635.6 \mathrm{~W}$, respectively.

- In a $3 \times 4$ array, the obtained maximum power of proposed SDTCTR with TCM (Prop_TCM) is superior than that of FCM and HCM under considered shadings cases.

- In a $4 \times 3$ array, the obtained maximum power of SDTCTR with TCM (Prop_TCM) is superior than that of FCM and HCM under four shading cases.

- In a $4 \times 4$ array, the obtained maximum power of SDTCTR with TCM (Prop_TCM) is superior than that of FCM and HCM under four shading cases. 


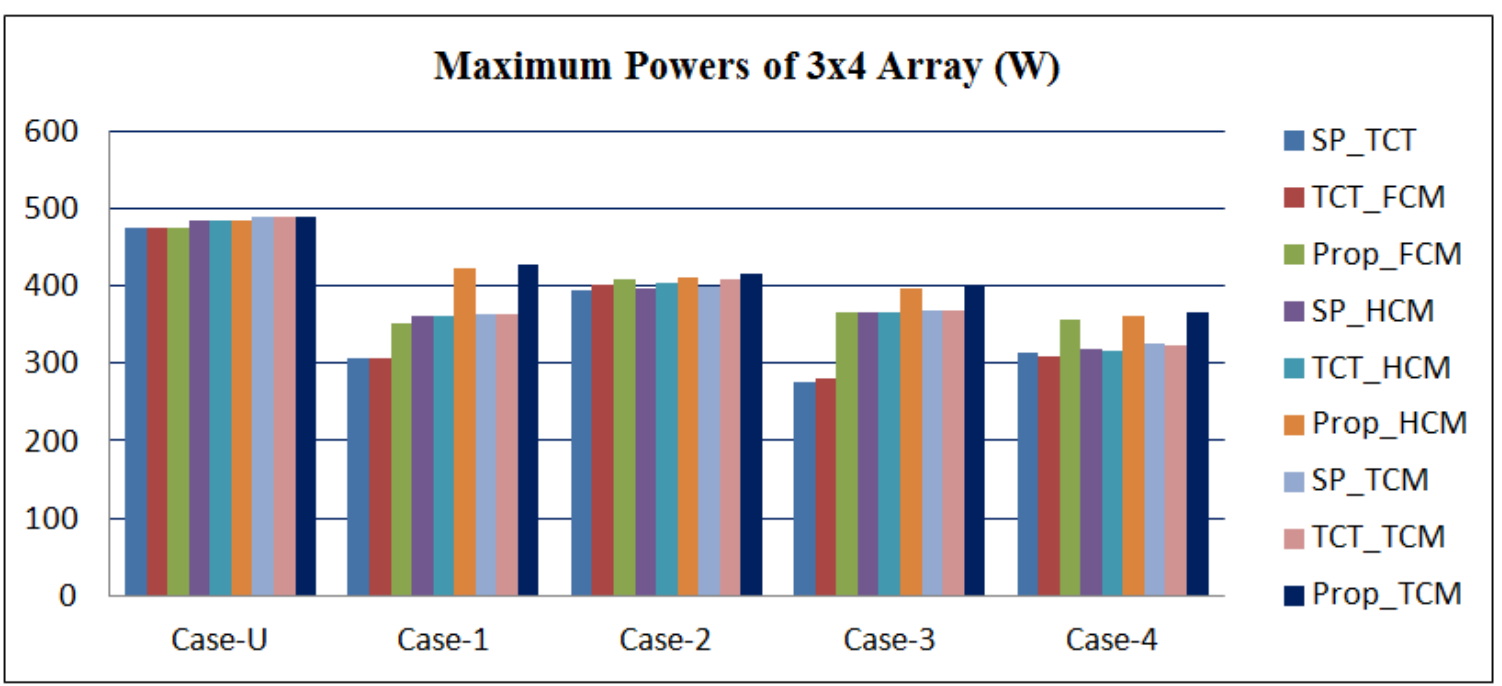

Figure 17. Power output from a $3 \times 4$ solar PV array under Cell Level Shading Cases

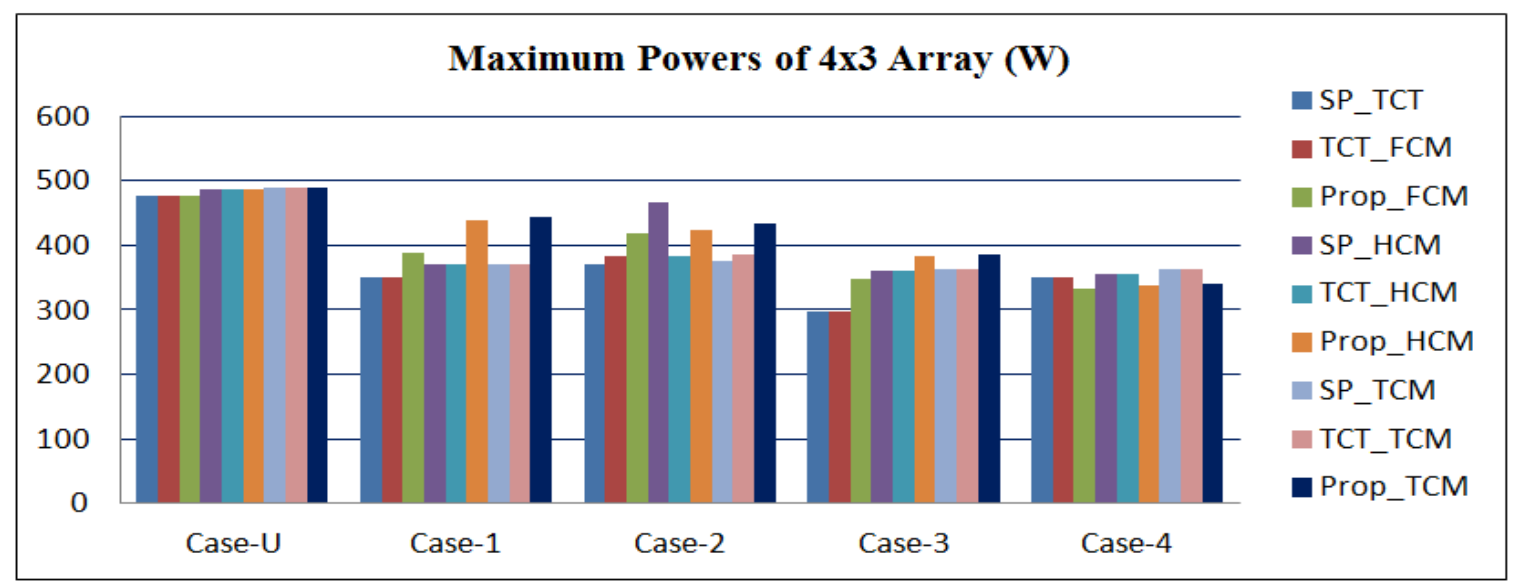

Figure 18. Power output from a $4 \times 3$ solar PV array under Cell Level Shading Cases

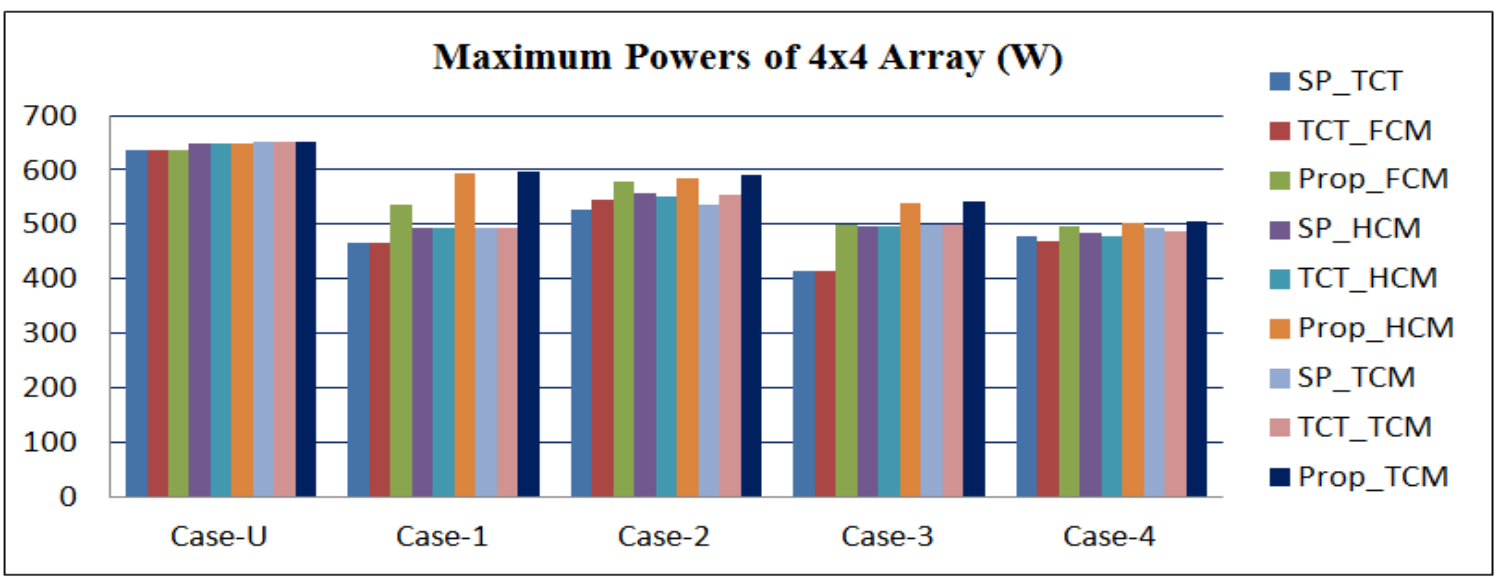

Figure 19. Power output from a $4 \times 4$ solar PV array under Cell Level Shading Cases

\section{CONCLUSIONS}

In this study, a simulation model for solar photovoltaic modules based on cell partition technique(PVM-CPT) was developed. The use of PVM-CPT can provide a 
significant advantage as well as increased performance in cell level shadowed conditions. Aligned with other energy generation advancements in half-cut and tri-cut cells, it is possible to achieve a large improvement in overall energy yield, making the new module based on CPT, a more attractive option for rooftop as well as grid connected energy generation. When the PVM-CPT is used, the current flow in a cell is reduced, which helps to eliminate the hotspot problems and a reduction in mismatch power loss while also improving overall performance. When comparing the Matlab/simulation results of HCM and TCM to full-size cell modules (FCM), we noticed an increase in fill factor and an increase in the maximum power. The HCM and TCM has a reduced power loss than a full-size-cell module with the same shade area. For solar cells with high short circuit current density of FCM, our modeling results demonstrate that employing PVM-CPT rather than FCM is even more advantageous. Finally, the performance of FCM, HCM and TCM connected in a $3 \times 4,4 \times 3$, and $4 \times 4$ array sizes with SP, TCT and proposed SD-TCTR connections are investigated and the results show that the proposed SD-TCTR with TCM is superior to standard full cell module (FCM) under all possible cell level shading conditions.

\section{Conflict of Interest}

The authors declare that there is no conflict of interests regarding the publication of this paper.

\section{REFERENCES}

[1] Mekhilef, S., Saidur, R., and Safari, A. (2011). A review on solar energy use in industries. Renewable and Sustainable Energy Reviews, 15(4), 1777-1790. DOI: 10.1016/j.rser.2010.12.018

[2] SolarPower Europe. (2019) Global Market Outlook For Solar Power / 2019 2023, https://www.solarpowereurope.org/wpcontent/uploads/2019/07/SolarPower-Europe Global-Market-Outlook-20192023.pdf (accessed on 11/25/2021)

[3] Kalogirou, S. (Ed.). (2017). McEvoy's handbook of photovoltaics: fundamentals and applications. Academic Press

[4] Seyedmahmoudian, M., Mekhilef, S., Rahmani, R., Yusof, R., and Renani, E. T. (2013). Analytical Modeling of Partially Shaded Photovoltaic Systems. Energies, 6(1), 128-144. DOI: 10.3390/en6010128

[5] Teo, J. C., Tan, R. H. G., Mok, V. H., Ramachandaramurthy, V. K., and Tan, C. (2018). Impact of Partial Shading on the P-V Characteristics and the Maximum Power of a Photovoltaic String. Energies, 11(7), 1860. DOI: 10.3390/en11071860

[6] Esram, T., and Chapman, P. L. (2007). Comparison of Photovoltaic Array Maximum Power Point Tracking Techniques. IEEE Transactions on Energy Conversion, 22(2), 439-449. DOI: 10.1109/TEC.2006.874230

[7] Belhachat, F., and Larbes, C. (2018). A review of global maximum power point tracking techniques of photovoltaic system under partial shading conditions. 
Renewable and Sustainable Energy Reviews, 92, 513-553. DOI:

10.1016/j.rser.2018.04.094

[8] Belhachat, F., and Larbes, C. (2015). Modeling, analysis and comparison of solar photovoltaic array configurations under partial shading conditions. Solar Energy, 120, 399-418. DOI: 10.1016/j.solener.2015.07.039

[9] Roeth, J., Facchini, A., and Bernhard, N. (2017). Optimized Size and Tab Width in Partial Solar Cell Modules including Shingled Designs. International Journal of Photoenergy, 2017, 3609109. DOI: 10.1155/2017/3609109

[10] Guo, S., Singh, J. P., Peters, I. M., Aberle, A. G., and Walsh, T. M. (2013). A Quantitative Analysis of Photovoltaic Modules Using Halved Cells. International Journal of Photoenergy, 2013, 739374. DOI: 10.1155/2013/739374

[11] Qian, J., Thomson, A., Blakers, A., and Ernst, M. (2018). Comparison of HalfCell and Full-Cell Module Hotspot-Induced Temperature by Simulation. IEEE Journal of Photovoltaics, 8(3), 834-839. DOI: 10.1109/JPHOTOV.2018.2817692

[12] Sarniak, M. T. (2020). Modeling the Functioning of the Half-Cells Photovoltaic Module under Partial Shading in the Matlab Package. Appl. Sci., 10(7), 2575. DOI:10.3390/app10072575

[13] Chiodetti, M., Dupuis, J., Boublil, D., Radouane, K., and Dupeyrat, P. (2019). Half-Cell Module Behaviour and Its Impact on the Yield of a PV Plant, in 36th European Photovoltaic Solar Energy Conference and Exhibition. pp. 1444 - 1448. DOI: 10.4229/Eupvsec20192019-5do.3.3

[14] Rooij, D.D. (2016). Half cut solar cells: new standard in product differentiation? https://sinovoltaics.com/solar-cells/half-cut-solar-cells-the-new-standard/ (accessed on 11/25/2021)

[15] Hanifi, H., Schneider, J., and Bagdahn, J. (2015). Reduced shading effect on halfcell modules-Measurement and simulation. In 31st European Photovoltaic Solar Energy Conference and Exhibition. pp. 2529-2533

[16] Qian, J., Clement, C. E., Ernst, M., Khoo, Y. S., Thomson, A., and Blakers, A. (2019). Analysis of Hotspots in Half Cell Modules Undetected by Current Test Standards. IEEE Journal of Photovoltaics, 9(3), 842-848. DOI:

10.1109/JPHOTOV.2019.2898209

[17] Mittag, M., Pfreundt, A., Shahid, J., Wöhrle, N., and Neuhaus, D. H. (2019). Techno-Economic Analysis of Half Cell Modules: The Impact of Half Cells on Module Power and Costs. In 36th European Photovoltaic Solar Energy Conference and Exhibition (EU PVSEC).

[18] Bala Raju, V. and Chengaiah, C. (2020). Mathematical Analysis of Solar Photovoltaic Array Configurations with Partial Shaded Modules. Trends in Renewable Energy, 6, 121-143. DOI: 10.17737/tre.2020.6.2.00115

[19] REC Solar Pte. Ltd. (2015). The REC Twin Peak Series: Innovative module design gives improved yield performance in shaded conditions, https://www.recgroup.com/sites/default/files/documents/whitepaper_twinpeak_sh ading properties eng.pdf (accessed on 11/04/2021)

[20] Ajmal, A. M., Sudhakar Babu, T., Ramachandaramurthy, V. K., Yousri, D., and Ekanayake, J. B. (2020). Static and dynamic reconfiguration approaches for 
mitigation of partial shading influence in photovoltaic arrays. Sustainable Energy Technologies and Assessments, 40, 100738. DOI: 10.1016/j.seta.2020.100738

[21] Bala Raju, V. and Chengaiah, C. (2020). A Comprehensive Study on Rearrangement of Modules Based TCT Configurations of Partial Shaded PV Array with Shade Dispersion Method. Tr Ren Energy, 6(1), 37-60. DOI: 10.17737/tre.2020.6.1.00111

[22] Vicente, P. d. S., Pimenta, T. C., and Ribeiro, E. R. (2015). Photovoltaic Array Reconfiguration Strategy for Maximization of Energy Production. International Journal of Photoenergy, 2015, 592383. DOI: 10.1155/2015/592383

[23] Parlak, K. Ş. (2014). PV array reconfiguration method under partial shading conditions. International Journal of Electrical Power \& Energy Systems, 63, 713 721. DOI: 10.1016/j.ijepes.2014.06.042

[24] Bala Raju, V. and Chengaiah, C. (2021). Enhance the Output Power of a Shaded Solar Photovoltaic Arrays with Shade Dispersion based TCT Configuration. Trends in Renewable Energy, 7, 1-23. DOI: 10.17737/tre.2021.7.1.00128

Article copyright: (C) 2022 V. Bala Raju, Dr. Ch. Chengaiah. This is an open access article distributed under the terms of the Creative Commons Attribution 4.0 International License, which permits unrestricted use and distribution provided the original author and source are credited. 